\title{
Role of innate lymphocytes in infection and inflammation
}

\author{
Shigeo Koyasu ${ }^{1,2,3}$ * and Kazuyo Moro ${ }^{1,2,4}$ \\ ${ }^{1}$ Department of Microbiology and Immunology, Keio University School of Medicine, Shinjuku-ku, Tokyo, Japan \\ 2 Laboratory for Immune Cell System, RIKEN Research Center for Allergy and Immunology, Yokohama, Kanagawa, Japan \\ ${ }^{3}$ Research Center for Science Systems, Japan Society for the Promotion of Science, Tokyo, Japan \\ ${ }^{4}$ Precursory Research for Embryonic Science and Technology (PRESTO), Japan Science and Technology Agency (JST), Chiyoda-ku, Tokyo, Japan
}

\section{Edited by:}

Brigitta Stockinger, MRC National

Institute for Medical Research, UK

\section{Reviewed by:}

Andrew McKenzie, Medical Research

Council Laboratory of Molecular

Biology, UK

Shinjiro Hamano, Institute of Tropical Medicine, Nagasaki University, Japan Mark Wilson, National Institute for

Medical Research, UK

\section{*Correspondence:}

Shigeo Koyasu, Department of Microbiology and Immunology, Keio University School of Medicine, 35 Shinanomachi, Shinjuku-ku, Tokyo 160-8582, Japan.

e-mail:koyasu@z3.keio.jp,

koyasu@rcai.riken.jp
Cooperation between the innate and adaptive immune responses is critical for enabling protective immunity against various invading microbes. Distinct types of effector $T$ cells have different functions in adaptive immune responses. Th1 cells play important roles in the control of intracellular bacteria by producing IFN- $\gamma$ to activate macrophages and in anti-viral immunity by producing IFN- $\gamma$ and activating cytotoxic $T$ lymphocytes. Th2 cellderived cytokines are important in activating mast cells, eosinophils, and goblet cells in anti-helminth immunity. Th17 cells are pivotal for the inflammatory response mediated by neutrophils, which resists extracellular bacterial infection. In all cases, it is critical that the innate immune responses limit the growth and expansion of invading microbes until antigen-specific adaptive immune responses are established. Recent studies have identified multiple subsets in innate lymphocytes corresponding to previously defined Th subsets. Classical natural killer cells, ROR $\gamma^{+}$lymphoid tissue inducer-related cells, and Th2-type innate lymphocytes play distinct roles in innate immune responses by producing Th1, Th17, and Th2 cytokines, respectively. Cooperation between innate lymphocytes and antigen-specific $T$ and $B$ cells are likely important in protective immunity against distinct types of microbes. The most recently identified subset is the ROR $\gamma$-independent Lin-Thy$1^{+}$IL-7R ${ }^{+}$GATA3 ${ }^{+}$innate lymphocyte subset such as natural helper $(\mathrm{NH})$ cell, which is Id2and IL-7-dependent. This population produces Th2 cytokines, most notably IL-5 and IL-13, and plays a major role in innate immune responses during anti-helminth immunity. In addition, these cells are likely involved in the pathophysiology of some types of allergic diseases. We summarize here current knowledge regarding various innate lymphocyte subsets. In particular, we focus on the Th2-type innate lymphocyte subset.

Keywords: Th2 cytokine, natural helper cell, fat-associated lymphoid cluster, nuocyte, innate helper type 2, helminth, asthma, allergic inflammation
Innate lymphocytes exhibit various effector functions such as limiting the expansion of microorganisms including viruses, bacteria, and parasites; unlike $\mathrm{T}$ and $\mathrm{B}$ cells, innate lymphocytes act without antigen-specific receptors. In addition to two prototypic innate lymphocyte populations, namely classical natural killer (cNK) cells and lymphoid tissue inducer (LTi) cells, multiple types of innate lymphocytes have been identified during the last decade. These include thymic natural killer (NK) cells, NK receptor-positive LTi cells, LTi cells producing IL-17 and IL-22 and Th2-type innate lymphocytes such as natural helper $(\mathrm{NH})$ cells and nuocytes. The transcription factor Id2 appears to be essential for the differentiation of all innate lymphocytes, suggesting the presence of a common progenitor population. Like helper $\mathrm{T}$ cell subsets in adaptive immune responses, NK cells, LTi cells, and Th2-type innate lymphocytes play distinct roles in innate immune responses by producing Th1, Th17, and Th2 cytokines, respectively (Figure 1). Cooperation

Abbreviations: CLP, common lymphoid progenitors; FALC, fat-associated lymphoid cluster; LMPP, lymphoid-primed multipotent progenitors; LTi, lymphoid tissue inducer; $\mathrm{NH}$, natural helper; NK, natural killer; TSLP, thymic stromal lymphopoietin. between those innate lymphocytes and antigen-specific $\mathrm{T}$ and $\mathrm{B}$ cells is likely important in protective immunity against various microbes. Here we review the properties of various innate lymphocytes and their effector functions.

\section{CONVENTIONAL NK CELLS}

$\mathrm{CD}^{-}{ }^{-} \mathrm{NKp} 46^{+} \mathrm{NK}$ cells comprise one of the classical innate lymphocyte populations (Walzer et al., 2007). However, recent studies have revealed that these cells contain both $\mathrm{CD} 127^{+}$(IL-7R $\alpha$ ) and CD127- cells (Satoh-Takayama et al., 2008; Luci et al., 2009; Sanos et al., 2009; Table 1). CD127- NKp46 ${ }^{+}$cells are cNK cells, which produce interferon- $\gamma($ IFN- $\gamma)$ and exhibit strong cytotoxicity (Trinchieri, 1989). cNK cells differentiate from lymphoid progenitor cells and the development of cNK cells requires the transcription factor E4BP4/NF-IL-3 (Gascoyne et al., 2009; Kamizono et al., 2009) and the cytokine IL-15 (Kennedy et al., 2000; Cooper et al., 2001; Ranson et al., 2003; Vosshenrich et al., 2005). cNK cells play an important role in innate immune responses against viral infection, and are particularly important in fighting herpes virus infections. cNK cells limit the propagation of viruses prior to the onset of adaptive immune responses associated with 
the expansion of virus-specific $\mathrm{CD}^{+}$cytotoxic $\mathrm{T}$ lymphocytes (Biron et al., 1999; Arase and Lanier, 2004). cNK cells recognize ligands that are induced on target cells by viral infection or cellular stresses using specific receptors such as CD94/NKG2D and exhibit cytotoxic activity via a variety of effector molecules such as perforin, granzyme, Fas-L, and TRAIL (Trinchieri, 1989; Biron et al., 1999; Arase and Lanier, 2004). NK cells differentiating in the thymus (thymic NK cells) are unique in that they express CD127 (IL-7R $\alpha$ ) and GATA3 unlike cNK cells. Thymic NK cells produce IFN- $\gamma$ and GM-CSF at much higher levels than $\mathrm{cNK}$ cells and their differentiation depends on the cytokine IL-7 and the transcription factor GATA3 (Vosshenrich et al., 2006; Ribeiro et al., 2010).

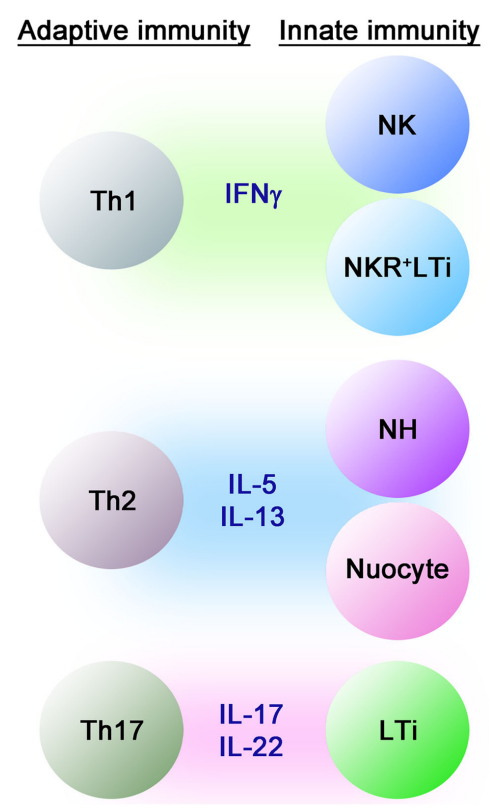

FIGURE 1 | Cytokine-producing cells in innate and adaptive immune systems. Just as for Th1, Th2, and Th17 cells in the adaptive immune system, NK cells, Th2-type innate lymphocytes and LTi cells play distinct roles in innate immune responses by producing Th1, Th2, and Th17 cytokines, respectively.

\section{ROR $\gamma^{+}$INNATE LYMPHOCYTES}

Lymphoid tissue inducer cells were originally defined as $\mathrm{Lin}^{-} \mathrm{CD} 4{ }^{+} \mathrm{CD} 117(\mathrm{c}-\mathrm{Kit}){ }^{+} \mathrm{CD} 127^{+} \mathrm{CD} 25(\mathrm{IL}-2 \mathrm{R} \alpha)^{+}$CD90(Thy$1)^{+}$cells (Mebius et al., 2001) but it was later shown that CD4 ${ }^{-}$LTi cells are abundantly observed in newborn mice (Sawa et al., 2010). LTi cells originate from $\mathrm{Lin}^{-} \mathrm{CD} 4^{-} \mathrm{CD} 117^{\text {int }} \mathrm{Sca}-1^{+} \mathrm{CD} 127^{+}$lymphoid progenitor cells in the fetal liver (Mebius et al., 2001). Their differentiation is dependent on the transcription factors ROR $\gamma$ and Id2, and IL-7 regulates their survival and activity (Mebius et al., 1997; Yokota et al., 1999; Sun et al., 2000; Eberl et al., 2004; Meier et al., 2007). LTi cells are present in the anlagen of both lymph nodes and Peyer's patches (Mebius et al., 1997; Sun et al., 2000; Eberl et al., 2004; Veiga-Fernandes et al., 2007; van de Pavert et al., 2009) and induce the formation of lymph nodes and Peyer's patches during fetal development (Mebius, 2003). Lymph nodes and Peyer's patches are missing in the absence of ROR $\gamma$ (Kurebayashi et al., 2000; Sun et al., 2000). Adult CD4 ${ }^{+}$LTi cells promote the maturation of tertiary lymphoid tissues after birth and the restoration of secondary lymphoid tissues after viral infection (Scandella et al., 2008; Tsuji et al., 2008). It is intriguing that the differentiation of adult, but not fetal. LTi is dependent on Notch signaling (Possot et al., 2011).

Earlier studies have shown that a population of CD4 ${ }^{+}$LTi cells generates lytic NK1.1 ${ }^{+}$cells after cultivation with IL-2 (Mebius et al., 1997; Yoshida et al., 2001), suggesting that LTi cells are progenitors of NK cells. It was later reported that, in humans, "immature NK cells" expressing CD127 and ROR $\gamma$ develop into NK cells (Cupedo et al., 2009; Hughes et al., 2009). However, a recent report showed that tonsillar $\mathrm{Lin}^{-} \mathrm{CD} 117^{+} \mathrm{CD} 127^{+}$cells maintain CD117 but do not acquire perforin or granzyme B expression after cultivation with irradiated PBMC, PHA, and IL-2 (Crellin et al., 2010a). On the other hand, tonsilar Lin $^{-}$CD $117^{+}$CD $127^{-}$ cells lose CD117 expression and acquire perforin, granzyme B, and several NK receptors. It is possible that the immature NK cells described previously (Freud et al., 2006; Cupedo et al., 2009; Hughes et al., 2009) contained both $\mathrm{CD}_{127^{+}} \mathrm{LTi}$ and immature cNK cells. Recent fate mapping analysis in mouse confirmed that cNK cells develop independently of LTi cells (Satoh-Takayama et al., 2010; Vonarbourg et al., 2010). In addition, E4BP4/NFIL3 is required for the differentiation of mouse cNK cells but there

Table 1 | Comparison between NK- and LTi-related cells.

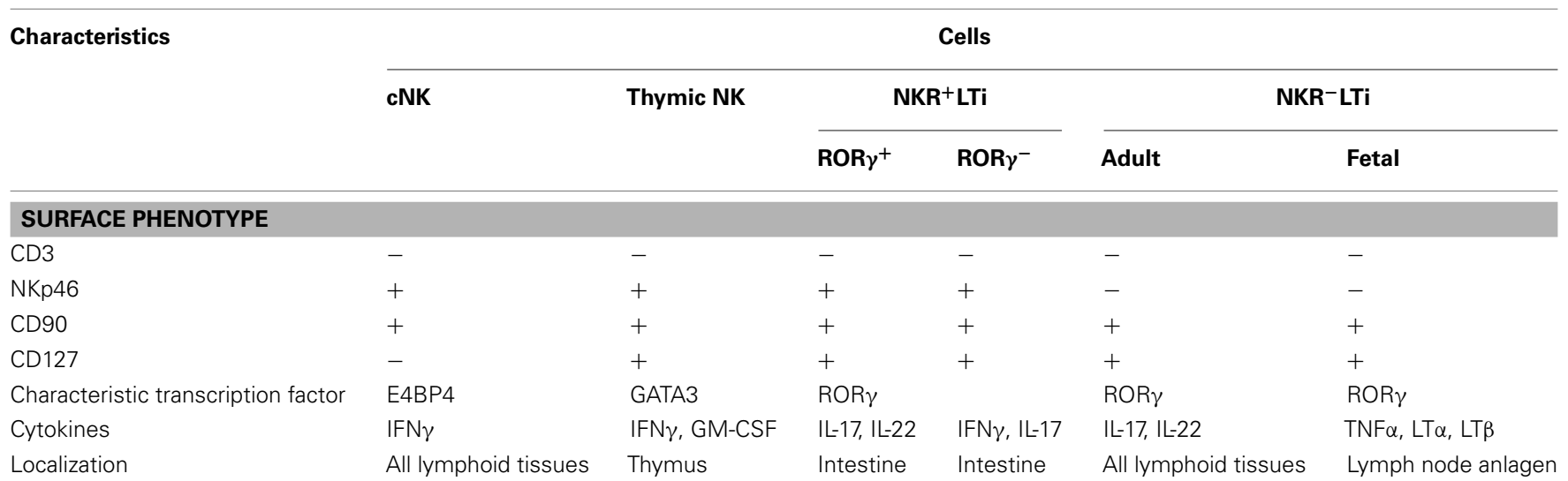


is currently no report of a deficiency of LTi-related cells in the absence of E4BP4/NFIL3.

Recent studies have shown the presence of $\mathrm{Lin}^{-} \mathrm{CD} 127^{+}$ $\mathrm{ROR} \gamma^{+} \mathrm{NKp} 46^{+}$innate lymphocytes sharing the characteristics of both NK and LTi cells $\left(\mathrm{NKR}^{+}\right.$LTi cells, Table 1). Because NKR ${ }^{+}$LTi produce IL-22, these cells are sometimes called NK22 (Cella et al., 2009), NCR22 (Satoh-Takayama et al., 2010), or ILC22 (Spits and Di Santo, 2011). Although these cells express NKp46, they exhibit little cytotoxic activity. Most $\mathrm{NKR}^{+} \mathrm{LTi}$ cells are present in the intestine while $\mathrm{NKR}^{-} \mathrm{LTi}$ cells are found in all lymphoid tissues (Reynders et al., 2011; Table 1). Approximately 90\% of NKp46 ${ }^{+}$ cells in the lamina propria of small intestine are $\mathrm{NKR}^{+}$LTi expressing CD127 and only $10 \%$ are cNK cells, both of which are absent in Id $2^{-1-}$ mice without affecting $\mathrm{T}$ cells (Satoh-Takayama et al.,

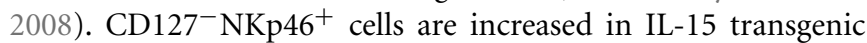
mice and $\mathrm{CD}_{127^{+}} \mathrm{NKp} 46^{-}$cells are decreased in $\mathrm{IL}-7^{-/-}$mice while total NKp46 ${ }^{+}$cells were unchanged in both cases (SatohTakayama et al., 2008), indicating the dependence of cNK cells on IL-15 and NKR ${ }^{+}$LTi cells on IL-7.

$\mathrm{NKR}^{+} \mathrm{LTi}$ cells are characterized by the expression of ROR $\gamma$ and IL-22 and their differentiation is dependent on ROR $\gamma$ while ROR $\gamma$ is not required for the differentiation of cNK cells (SatohTakayama et al., 2008; Luci et al., 2009; Sanos et al., 2009). ROR $\gamma$ fate mapping analysis using rorc-Cre mice (Lochner et al., 2008), in which Cre recombinase is inserted into the rorc locus encoding ROR $\gamma$, that were further crossed with loxP-flanked YFP Rosa26 (Rosa-YFP) mice (Srinivas et al., 2001) revealed that $\mathrm{YFP}^{+}$cells that have previously expressed ROR $\gamma$ (herein $\mathrm{ROR} \gamma^{\mathrm{fm}}+$ cells) were either LTi cells ( $\mathrm{NKR}^{-} \mathrm{LTi}$ cells) or $\mathrm{NKR}^{+} \mathrm{LTi}$ cells and no $\mathrm{cNK}$ cells in the bone marrow, spleen, liver, or lymph nodes were $\operatorname{ROR} \gamma^{\mathrm{fm}+}$ (Satoh-Takayama et al., 2010; Vonarbourg et al., 2010; Figure 2). $\mathrm{ROR} \gamma^{\mathrm{fm}+}$ cells are composed of both $\mathrm{NKp} 6^{+}$and $\mathrm{NKp} 46^{-}$populations and $\mathrm{NKp} 46^{-} \mathrm{ROR} \gamma^{\mathrm{fm}+}$ cells are identical to
LTi cells. LTi cells express CD25 and CCR6 but NKR ${ }^{+}$LTi cells do not express CD25 or CCR6. $\mathrm{NKR}^{+}$LTi cells are CD4 ${ }^{\mathrm{fm}+}$, indicating that these cells are derived from $\mathrm{CD} 4{ }^{+} \mathrm{ROR} \gamma^{+} \mathrm{LTi}$ cells (Figure 2). Notably, ROR $\gamma^{-} \mathrm{NKR}^{+} \mathrm{LTi}$ cells produce IFN $\gamma$ as cNK cells (Satoh-Takayama et al., 2010; Vonarbourg et al., 2010; Table 1). ROR $\gamma^{-} \mathrm{NKR}^{+}$LTi cells and thymic NK cells share some characteristics but their cytokine production profiles are different (Table 1). In the human, the $\mathrm{CD}^{-} \mathrm{CD} 127^{+} \mathrm{NKp} 44^{+}$cell population expresses ROR $\gamma$ and is a counterpart of the $\mathrm{NKR}^{+} \mathrm{LTi}$ population in mouse (Cella et al., 2009; Cupedo et al., 2009; Crellin et al., 2010a).

Adult LTi cells provide effector functions by producing IL-17 and IL-22 (Cupedo et al., 2009; Takatori et al., 2009). LTi cells producing high levels of these cytokines are $\mathrm{CD}^{-}$and are sometimes called ILC17 (Spits and Di Santo, 2011). Production of IL-17 and IL-22 is further enhanced in vitro upon stimulation with IL-23 (Cella et al., 2009; Buonocore et al., 2010). LTi cells also produce IL-17 and IL-22 in vivo in response to zymosan (Takatori et al., 2009) or flagellin (Van Maele et al., 2010) but LTi cells do not directly respond to microbe-derived substances. Other cells such as dendritic cells and macrophages likely mediate the effects of zymosan and flagellin.

$\mathrm{NKR}^{+}$LTi cells are mainly present in lamina propria of the intestinal mucosa and are important in innate immune responses against Citrobacter rodentium (Satoh-Takayama et al., 2008; Zheng et al., 2008; Luci et al., 2009; Sanos et al., 2009). IL-22 is an important cytokine in the activation and defense of epithelial cells (Zenewicz et al., 2008; Wolk et al., 2010). Because IL-22 induces the production of antimicrobial peptides such as $\beta$-defensin psoriasin, calgranulin A, calgranulin B, RegIII $\beta$, and RegIII $\gamma$ by epithelial cells (Wolk et al., 2004, 2006; Zheng et al., 2008), IL-22 is important for protection against C. rodentium (Zheng et al., 2008; Sonnenberg et al., 2011), Klebsiella pneumoniae (Happel et al., 2005; Aujla

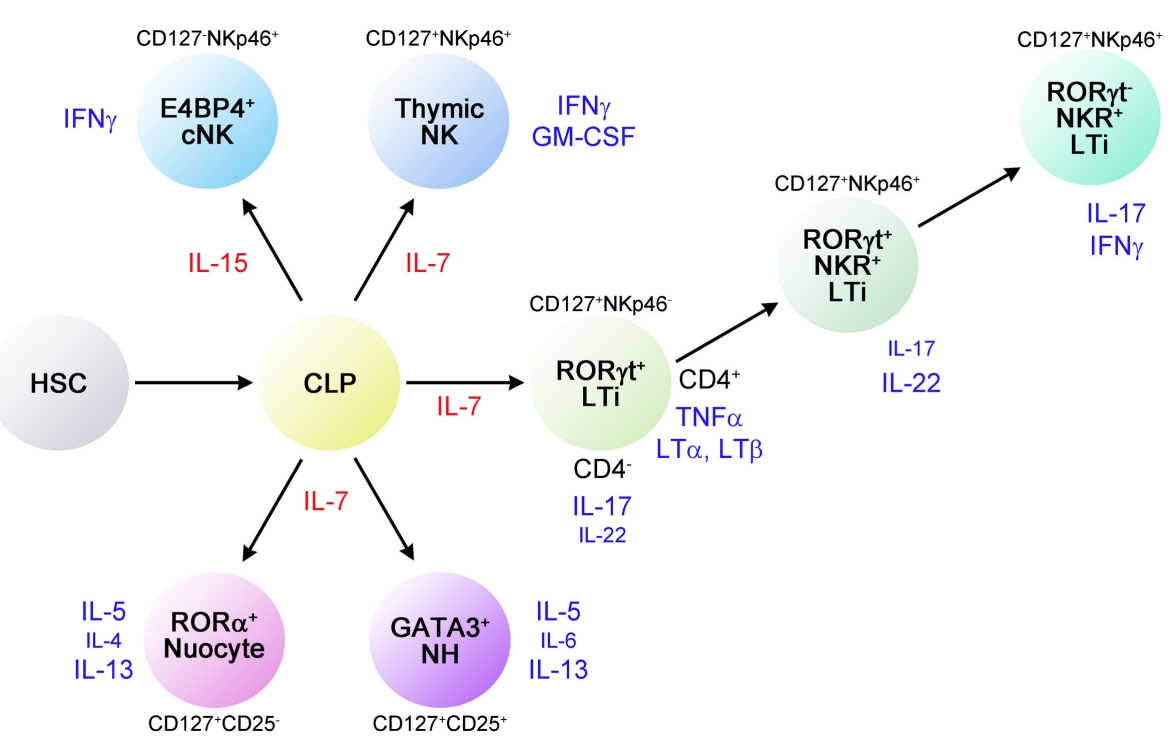

FIGURE 2 | Developmental relationships between various innate lymphocytes. Cytokines and transcription factors involved in the differentiation of innate lymphocyte subsets are shown. The plasticity of ROR $\gamma^{+}$LTi-related innate lymphocytes is noted as shown here but the relationship between NH cells and nuocytes is currently unknown. 
et al., 2008), and Candida albicans (De Luca et al., 2010). Thus, $\mathrm{NKR}^{+}$LTi cells play a major role in the innate immune responses against those microbes through the production of IL-22.

Lymphoid tissue inducer-related cells are also involved in the pathophysiology of some forms of inflammatory colitis (Buonocore et al., 2010; Vonarbourg et al., 2010). Inflammatory colitis induced by administration of anti-CD40 $\mathrm{mAb}$ is not induced in $\gamma \mathrm{c}^{-/-} \mathrm{rag}^{-/-}$mice lacking all innate lymphocytes but adoptive transfer of $\mathrm{NKR}^{+} \mathrm{LTi}$ cells restores the induction of colitis. Intriguingly, IL-23-responsive IFN- $\gamma$-producing innate lymphocytes were found in the lamina propria of inflammatory bowel disease patients (Takayama et al., 2010), implying the involvement of innate lymphocytes in human diseases. Intestinal flora does not affect the number of LTi cells but affects the function of LTi cells (Sawa et al., 2011). Expression of IL-22 but not IL-17 is higher in germ-free mice than in SPF mice and antibiotic treatment in SPF mice increased the expression of IL-22. IL-22 expression was higher in $i l 25^{-1-}$ LTi cells and administration of IL-25 suppressed IL-22 expression in wild type LTi cells, suggesting that epithelial cell-derived IL-25 suppressed IL-22 production (Sawa et al., 2011). The effect of IL-25 is indirect because LTi cells do not express IL25 receptors (IL-17RB). It is likely that IL-17RB ${ }^{+}$dendritic cells suppress IL-22 production in a contact-dependent manner.

\section{Th2 CYTOKINE-PRODUCING INNATE LYMPHOCYTES}

The third subset of innate lymphocytes identified most recently is the $\mathrm{ROR} \gamma$-independent $\mathrm{Lin}^{-} \mathrm{CD} 90^{+} \mathrm{CD} 127^{+} \mathrm{GATA}^{+}$innate lymphocyte subset, which is Id2- and IL-7-dependent (Figure 2). This population is capable of producing Th2 cytokines, most notably IL-5 and IL-13, but not IL-4. This Th2 cytokine-producing subset was first reported in 2010 and named NH cells (Moro et al., 2010), MPPtype2 (Saenz et al., 2010), nuocytes (Neill et al., 2010), or innate helper type 2 (Ih2) cells (Price et al., 2010). Among these reports, $\mathrm{NH}$ cells were identified in naïve animals while all other cell types were observed upon cytokine administration or helminth infection in cytokine-GFP reporter mice. Although their relationships are currently unclear, NH cells, nuocytes, and Ih2 cells share similar characteristics (Table 2). MPPtype2 cells seem to be of myeloid lineage. It remains to be determined how many cell types are present in this subset.

Th2 activity is important for anti-helminth immunity (McKenzie et al., 1998; Urban et al., 1998; Perrigoue et al., 2008; Maizels et al., 2009). In addition, Th2 reactions are involved in the pathophysiology of various allergic diseases including asthma (Grünig et al., 1998; Walter et al., 2001; Larché et al., 2003; Holgate and Polosa, 2008). Although the antigen-specific Th2 response plays a central role both in protective immunity against helminths and antigen-specific allergic responses, accumulating evidence indicates the involvement of innate immune cells in the early phase of Th2 responses.

Recent studies shed light on the role of epithelial cells in regulating Th2 responses. Epithelial cell-derived thymic stromal lymphopoietin (TSLP), IL-25 and IL-33 have been implicated in regulating Th2-type innate immune responses (Fort et al., 2001; Soumelis et al., 2002; Schmitz et al., 2005; Zaph et al., 2007). These cytokines induce Th2-type cytokines from various cells (Min et al., 2004; Gessner et al., 2005; Voehringer et al., 2006; Saenz et al., 2008;
Table 2 | Comparison between Th2-type innate lymphocytes.

\begin{tabular}{|c|c|c|c|c|c|}
\hline \multirow[t]{3}{*}{ Characteristics } & \multicolumn{5}{|c|}{ Cells } \\
\hline & \multirow[t]{2}{*}{ NH cell } & \multirow[t]{2}{*}{ Nuocyte/lh2 } & \multirow{2}{*}{$\begin{array}{l}\text { Innate IL-9 } \\
\text { producer }\end{array}$} & \multicolumn{2}{|c|}{ MPPtype2 } \\
\hline & & & & GFP $^{-}$ & GFP $^{+}$ \\
\hline \multicolumn{6}{|c|}{ SURFACE PHENOTYPE } \\
\hline CD45 & + & + & + & & \\
\hline Sca-1 & + & + & $+/-$ & + & + \\
\hline CD90 & + & + & & & \\
\hline CD34 & - & - & & $+/-$ & $+/-$ \\
\hline CD44 & + & + & & & \\
\hline $\mathrm{F}_{c \varepsilon \mathrm{R}}$ & - & - & & & \\
\hline IL-17RB & + & + & & & \\
\hline CD127 & + & + & - & - & $+/-$ \\
\hline ICOS & + & ++ & & & \\
\hline CD117 & + & $+/-$ & - & + & + \\
\hline T1/ST2 & + & $+/-$ & + & $+/-$ & $+/-$ \\
\hline CD25 & + & - & $+/-$ & & \\
\hline MHC class II & - & + & $+/-$ & $+^{*}$ & $+/-^{*}$ \\
\hline \multicolumn{6}{|c|}{ LOCALIZATION } \\
\hline FALC & + & - & & & \\
\hline Lymph nodes & - & + & + & + & + \\
\hline Lung & $+^{* *}$ & $+{ }^{* *}$ & $+{ }^{* *}$ & & \\
\hline \multicolumn{6}{|c|}{ CYTOKINE RESPONSIVENESS } \\
\hline IL-2 & + & + & + & & \\
\hline IL-25 & - & $+{ }^{* * *}$ & - & $+^{* * *}$ & $+{ }^{* * *}$ \\
\hline IL-2 + IL-25 & + & + & & & \\
\hline IL-33 & + & $+/-^{* * * *}$ & & + & \\
\hline IL-7 + IL-33 & + & + & & & \\
\hline
\end{tabular}

${ }^{*}$ After cultivation with IL-3 and SCF.

${ }^{*}$ Mostly after administration of papain or IL-33, and helminth infection.

***These cells were induced by IL-25 in vivo.

*** IL-33 alone induces only moderate proliferation.

Sokol et al., 2008; Terashima et al., 2008). TSLP was originally identified from thymic stromal cells and thought to support the growth and differentiation of $\mathrm{T}$ and $\mathrm{B}$ cells but is now considered to be a Th2-inducing cytokine (Eisenbarth et al., 2002). TSLP acts to induce dendritic cells capable of differentiating naïve CD4 ${ }^{+} \mathrm{T}$ cells to Th2 cells (Soumelis et al., 2002; Ying et al., 2005). IL-33 induces the production of Th2-type cytokines from mast cells (Ho et al., 2007), basophils (Kondo et al., 2008), eosinophils (Perrigoue et al., 2009), CD4 ${ }^{+} \mathrm{T}$ cells (Louten et al., 2011), CD8 ${ }^{+} \mathrm{T}$ cells (Yang et al., 2011a), Tregs (Brunner et al., 2011), and CD11b ${ }^{+}$ innate cells (Turnquist et al., 2011). IL-25 activates NKT cells (Terashima et al., 2008) and CD117 ${ }^{+}$non-T, non-B cells (Fallon et al., 2006; Perrigoue et al., 2009) and induces proallergic type 2 responses (Angkasekwinai et al., 2007). Administration of IL-25 and IL-33 induces rapid production of Th2-type cytokines such as IL-5 and IL-13 in mice independently of T or B cells (Fort et al., 2001; Hurst et al., 2002; Humphreys et al., 2008), suggesting that Th2 cytokine-producing innate lymphocytes, i.e., Th2-type innate lymphocytes, are regulated by those epithelial cell-derived 
cytokines. $\mathrm{CD} 117^{+}$non-T, non-B cells were not induced in $i l 25^{-1-}$ mice upon helminth infection (Fallon et al., 2006), indicating that these cells do not responds to IL-33.

Natural helper cells were discovered in adipose tissues and are present in lymphoid clusters termed fat-associated lymphoid clusters or FALC (Moro et al., 2010). In addition to CD90 and CD127, NH cells isolated from FALC express CD117, Sca-1, CD25, CD44, CD45, CD69, $\alpha 4 \beta 7$, ICOS, IL-17RB (IL-25R), and T1/ST2 (IL33R) but lack MHC class II, Flt3, and conventional lineage markers. $\mathrm{NH}$ cells were also observed in the bone marrow (Brickshawana et al., 2011 and our unpublished observation) although the expression level of CD117 is very low in the bone marrow. NH cells were also observed in the lung of naïve mice although the numbers are small (Monticelli et al., 2011; Halim et al., 2012; Ikutani et al., 2012). IL-7 supports the survival of NH cells and IL-2 induces their proliferation (Moro et al., 2010). Neither FALC NH cells nor lung $\mathrm{NH}$ cells differentiate under myeloid differentiation conditions. NH cells do not differentiate to T cells upon culture on OP1 stromal cells expressing delta-like 1 or upon intrathymic transfer (Moro et al., 2010; Yang et al., 2011b).

In terms of transcription factors involved in the differentiation of lymphocytes, NH cells express Id2 and GATA3 but lack ROR $\gamma$. FALC and NH cells are present in $\operatorname{rorc}(R O R \gamma)$-deficient mice, indicating that LTi are not involved in FALC formation or in the differentiation of $\mathrm{NH}$ cells. Notable characteristics of $\mathrm{NH}$ cells are their abilities to constitutively produce IL-5, IL-6, and IL-13 and to support IgA production from B cells in vitro as well as self-renewal of $\mathrm{B} 1$ cells in vitro and in vivo (Figure $3 \mathbf{A}$ ). Upon activation with IL-33, NH cells produce large amounts of IL-5 and IL-13 (Figure 3B) and the amounts produced by 5,000 cells for 5 days reach microgram quantities. IL-25 alone does not activate $\mathrm{NH}$ cells but a combination of IL-2 plus IL-25 activates NH cells to produce IL-5 and IL-13. It should be noted that NH cells express mRNA for IL-4 but IL-4 protein is induced only by a combination of phorbol 12-myristate 13-acetate and ionomycin and not by
IL-33 or IL-2 + IL-25. Intranasal administration of IL-33 induces $\mathrm{NH}$ cells in the lung and bronchoalveolar lavage fluid associated with eosinophilia and IL-25 was much less potent in inducing $\mathrm{NH}$ cells than IL-33 (Wilhelm et al., 2011; Bartemes et al., 2012; and our unpublished observations).

Natural helper cells play an important role in the innate immune response against helminth infection (Koyasu et al., 2010). Nippostrongylus brasiliensis is a model for the migratory pathway of the human hookworm, which infects subcutaneously, enters vasculature, migrates to the lungs, molts, penetrates the alveoli, and ascends the trachea, where the worms are swallowed to complete maturation in the small intestine (Hotez et al., 2004). Adult worms are cleared after 8-10 days by a Th2 response (Urban et al., 1998). Among Th2 cytokines, IL-13 is critical for goblet cell hyperplasia, which is important for anti-helminth Th2 immunity (Urban et al., 1998; Mohrs et al., 2005). il4 ${ }^{-l-}$ mice show lower Th2 response but are able to expel the worms (Kopf et al., 1993) but $i l 13^{-1-}$ mice are impaired in goblet cell hyperplasia and are unable to expel the worms (Urban et al., 1998; McKenzie et al., 1999). IL-13, in addition to IL-5, is important in inducing eosinophilia (Wynn, 2003). Mice deficient for both $\gamma c$ and rag-2 lack NH cells in addition to T, B, and NK cells. $\gamma c^{-1-}$ rag- $2^{-1-}$ mice produce neither IL-5 nor IL-13 and are impaired in goblet cell hyperplasia upon $N$. brasiliensis infection. Administration of IL-33 fails to induce IL-5 and IL-13 production in $\gamma \mathrm{c}^{-1-} \mathrm{rag}-2^{-1-}$ mice. Adoptive transfer of $\mathrm{NH}$ cells isolated from FALC restored goblet cell hyperplasia along with the production of IL-5 and IL-13 (Moro et al., 2010). $\mathrm{NH}$ cells likely contribute to the early production of IL-5 and IL13 upon $N$. brasiliensis infection, which induces eosinophilia and goblet cell hyperplasia (Figure 3B).

Natural helper cells are present in $\mathrm{rag} 2^{-1-}$ and $n u / n u$ mice but absent in $i d 2^{-l-}, \gamma c^{-l-}, i l 7^{-1-}$, and $c d 127^{-1-}$ mice (Moro et al., 2010; Yang et al., 2011b). As expected, NH cells are derived from common lymphoid progenitors (CLPs) and lymphoid-primed multipotent progenitors (LMPP), the latter of which retain some

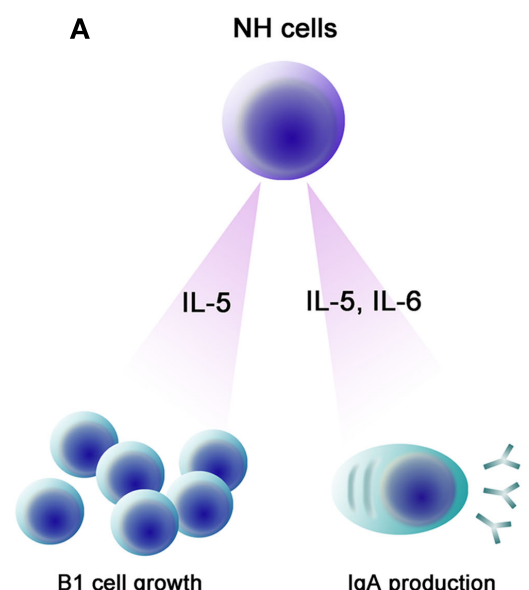

FIGURE 3 | Functions of NH cells. (A) IL-5 and IL-6 constitutively produced by $\mathrm{NH}$ cells support IgA production by $\mathrm{B}$ cells. IL-5 supports the growth of B1 cells in the peritoneal cavity. (B) Upon helminth infection, IL-33 produced by epithelial cells, endothelial cells, and/or adipocytes induces high levels of IL=5

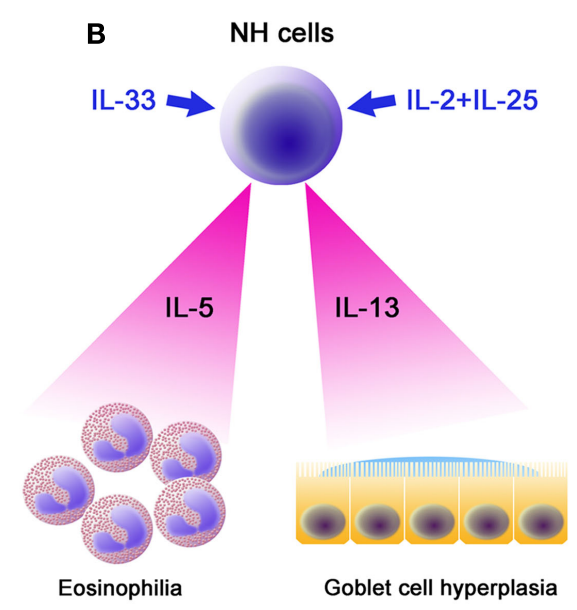

and IL-13 by $\mathrm{NH}$ cells, resulting in eosinophilia and goblet cell hyperplasia, which play important roles in an early phase of anti-helminth immune responses. Similarly, a combination of IL-2 and IL-25 (IL-2 + IL-25) also induces large amounts of IL-5 and IL-13 from NH cells. 
myeloid potential (Igarashi et al., 2002; Welner et al., 2009). In ragl-cre mice crossed with Rosa-YFP mice, more than half of $\mathrm{NH}$ cells are Rag ${ }^{\mathrm{fm}+}$ (Yang et al., 2011b), indicating the close relationship between NH cells and T/B lymphocytes. Cell transfer analysis showed that $\mathrm{NH}$ cells were generated from hematopoietic stem cells, LMPPs, and CLPs (Yang et al., 2011b). LMPPs were more efficient at generating NH cells than CLPs, which is similar to the case of T cells (Schwarz et al., 2007; Serwold et al., 2009). Lymphoid progenitor-derived NH cells express a high level of GATA3 as expected. Again, they expressed il 4 mRNA but no IL-4 protein was detected.

Neill et al. (2010) generated il13-eGFP reporter mice and demonstrated that administration of IL-25 or IL-33 induced a $\mathrm{GFP}^{+}$population in the mesenteric lymph nodes ( $\sim 3 \%$ of total cells in mesenteric lymph nodes), $\sim 80 \%$ of which were cells of unknown lineage. Only a small number of $\mathrm{GFP}^{+}$cells were present in the spleen, mesenteric lymph nodes, and bone marrow of naïve mice $(<0.2 \%)$ but administration of IL-25 or IL-33 significantly increased the number of $\mathrm{GFP}^{+}$cells in these organs with the exception of bone marrow. $\mathrm{GFP}^{+}$cells were named nuocytes as the 13th letter of the Greek alphabet is nu. IL-25-elicited nuocytes are present in the mesenteric lymph nodes, intestinal lamina propria, and spleen and express CD117, Sca-1, CD43, CD45, CD132, CD127, $\beta 7$, CD90, ICOS, MHC class II, CD44, CD49d, ICAM1, IL-17RB, T1/ST2, and CCR9. Nuocytes express MHC class II but not $\mathrm{CD} 25$, which is different from naïve $\mathrm{NH}$ cells that express CD25 but not MHC class II (Table 2; Moro et al., 2010; Neill et al., 2010). IL-33-elicited $\mathrm{GFP}^{+}$cells were also observed in mesenteric lymph nodes, spleen, and intestinal lamina propria. The authors

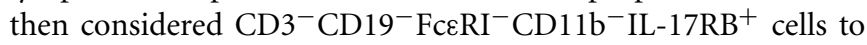
be nuocytes and reported that induction of nuocytes was unaffected in rag2 ${ }^{-1-}, W^{\text {sh/sh }}, j \alpha 18^{-1-}$, and rorc $^{-1-}$ mice but impaired in roar ${ }^{-1-}$ mice (Neill et al., 2010; Wong et al., 2012). In vitro culture of $10^{6} / \mathrm{ml}$ nuocytes prepared from spleens of IL-25-treated wild type mice produced microgram levels of IL-5 and IL-13 in response to IL-7 + IL-33 (Neill et al., 2010). Unlike NH cells, nuocytes are reported to produce IL-4 (Wong et al., 2012). In contrast to nuocytes, NH cells are not found in lymph nodes and, in fact, do not express the chemokine receptors necessary for lymphocyte recruitment to the lymph node even with activation (our unpublished observations), which further discriminates $\mathrm{NH}$ cells from nuocytes. Because NH cells produce a large amount of IL-13 in response to IL-33, it is likely that IL-33-elicited $\mathrm{GFP}^{+}$cells contain both $\mathrm{NH}$ cells and nuocytes while the majority of IL-25-elicited $\mathrm{GFP}^{+}$cells are nuocytes.

Nippostrongylus brasiliensis infection also induced $\mathrm{GFP}^{+}$cells in the intestinal lamina propria of ill3-eGFP reporter mice (Neill et al., 2010). ill7r $r^{-1-}$ mice expelled $N$. brasiliensis more slowly than wild type mice and worm expulsion was severely impaired in ill7rb ${ }^{-1-}$ illrl1 ${ }^{-1-}$ mice lacking both IL-17RB and T1/ST2. The lack of either IL-17RB or T1/ST2 in il13-eGFP reporter mice greatly reduced the appearance of $\mathrm{GFP}^{+}$cells in mesenteric lymph nodes. $i l 17 r b^{-I-}$ mice exhibited impaired IL-25triggered eosinophilia in the peritoneal cavity and impaired goblet cell hyperplasia in the intestine. $\mathrm{Lin}^{-} \mathrm{CD}_{4} 5^{+} \mathrm{ICOS}^{+}$cells sorted from splenocytes of IL-25-treated wild type mice were defined as nuocytes and adoptive transfer of such nuocytes restored both eosinophilia and goblet cell hyperplasia. Worm expulsion is dependent on $\mathrm{T}$ cells and rag $2^{-1-}$ mice cannot expel worms even after transfer of wild type nuocytes. Nuocyte numbers in mesenteric lymph nodes increased in rag2 $2^{-1-}$ mice on day 4 after infection of rag $2^{-/-}$mice but rapidly decreased on day 6 , suggesting that the expansion of nuocytes is T and/or B cell-dependent.

Intriguingly, two groups (Price et al., 2010; Saenz et al., 2010) have reported the induction of different types of $\mathrm{GFP}^{+}$cells in the same il4-eGFP reporter mice (4-get mice; Mohrs et al., 2001) upon IL-25 or IL-33 administration. Saenz et al. (2010) observed that administration of IL-25 to 4 -get mice increased a CD117 ${ }^{+}$ non-T, non-B population $\sim 60$-fold in mesenteric lymph nodes and that this was associated with the increase of $i l 4, i l 5$, and $i l 13$ mRNAs in the large intestine (Saenz et al., 2010). GFP cells in the Peyer's patches and mesenteric lymph nodes were CD11 $17^{\text {int }}$ compared to mast cells and were present in $W^{\text {sh/sh }}$ mice. Intraperitoneal administration of IL-25 did not induce $\mathrm{GFP}^{+}$cells in the spleen or bone marrow or increase the frequency of $\mathrm{NH}$ cells in the mesentery (Saenz et al., 2010). The CD117 int population did not express gata 3 , junb, c-maf, stat 6 , or $t 1 /$ st 2 mRNAs. N. brasiliensis infection also induced a CD117 ${ }^{\text {int }}$ population in mesenteric lymph nodes in an IL-17RA- and IL-17RB-dependent manner. Administration of anti-IL-25 antibodies reduced the number of cells in the CD117 int population after $N$. brasiliensis infection. The $\mathrm{CD} 117^{\text {int }}$ population contains both $\mathrm{GFP}^{+}$and $\mathrm{GFP}^{-}$ cells; $\mathrm{GFP}^{+}$cells were $\mathrm{Lin}^{-} \mathrm{T} 1 / \mathrm{ST} 2^{\mathrm{lo} /-} \mathrm{CD} 127^{\mathrm{lo} /-}$ and $\mathrm{GFP}^{-}$cells were $\mathrm{Lin}^{-} \mathrm{T} 1 / \mathrm{ST} 2^{\mathrm{lo} /-} \mathrm{CD} 127^{-}$, indicating that there are at least two $\mathrm{CD} 117^{\text {int }}$ populations induced by IL- 25 and $N$. brasiliensis infection.

$i l 25^{-1-}$ mice produced only low levels of Th2-type cytokines and parasite-specific IgG1 upon Trichuris muris infection and were susceptible to T. muris infection. Adoptive transfer of IL25 -elicited wild type $\mathrm{CD} 117^{\text {int }}$ cells restored the immune response and protective immunity against $T$. muris in $i l 25^{-1-}$ mice, indicating a role for this population in anti-helminth immunity. In an in vitro culture system, $\mathrm{GFP}^{+}$cells gave rise to mast cells in the presence of SCF and IL-3. GFP ${ }^{-}$cells became mast cells, basophils, and macrophages in the presence of SCF and IL-3 with or without OP9 stromal cells. Because of such myeloid potential, it is unlikely that these cells were of lymphoid lineage and thus were named MPP ${ }^{\text {type2}}$ for multipotent progenitor cell type 2 (Saenz et al., 2010). Such myeloid differentiation potential and the lack of gata3 expression discriminate MPP $\mathrm{P}^{\mathrm{type} 2}$ from $\mathrm{NH}$ cells.

Price et al. (2010) reported that the 4-get mouse has $\mathrm{Lin}^{-} \mathrm{CD} 117^{\mathrm{lo}} \mathrm{CD} 90^{+} \mathrm{GFP}^{+}$cells in multiple tissues including liver, mesenteric lymph nodes, spleen, and bone marrow. This population, named Ih2 cells, was present in rag2 ${ }^{-/-}, W^{\text {sh/sh }}, \Delta$ dblgata mice but absent in $\gamma \mathrm{c}^{-1-}$ mice. Ih2 cells seem closer to nuocytes than to NH cells because Ih2 cells and nuocytes are present in lymph nodes, while, as mentioned above, $\mathrm{NH}$ cells were not present in lymph nodes. Mice in which YFP-Cre was inserted into the ill3 coding region (YetCre13 mice) that were further crossed with RosaYFP mice have $\mathrm{Lin}^{-} \mathrm{CD} 117^{\mathrm{lo}} \mathrm{IL}-13^{\mathrm{fm}+}$ cells, which were similar to the $\mathrm{GFP}^{+}$cells observed in 4-get mice. It is intriguing that $\mathrm{GFP}^{+}$ cells in 4-get mice do not produce IL-4 at the protein level, which indicates that reporter expression does not always correlate with the expression of the original gene product. 
Administration of $500 \mathrm{ng}$ of IL-25 or IL-33 for four consecutive days to 4-get mice increased $\mathrm{GFP}^{+}$cells in mesenteric lymph nodes, spleen, liver, and peritoneum; this was associated with an increase in eosinophils. Administration of IL-25 to mice obtained from YetCre13 mice crossed with Rosa-flox-Stop-diophtheria toxin $\alpha$ mice and 4 -get mice greatly reduced $\mathrm{Lin}^{-} \mathrm{CD}^{-} 117^{\mathrm{lo}} \mathrm{GFP}^{+}$cells and eosinophils in mesenteric lymph nodes, spleen, liver, and peritoneum. $N$. brasiliensis infection also increased this population in mesenteric lymph nodes, spleen, and lung. rag $2^{-1-}$ but not $\gamma c^{-1-}$ rag $2^{-1-}$ mice were able to clear $N$. brasiliensis after administration of IL-25 for four consecutive days. Adoptive transfer of $\mathrm{Lin}^{-} \mathrm{CD} 117^{\text {lo }} \mathrm{GFP}^{+}$cells from YetCre13 mice crossed with 4-get mice into $\gamma \mathrm{c}^{-1-}$ rag2 $2^{-1-}$ mice did not result in clearance of the worms but administration IL-25 in addition to the transfer of $\mathrm{Lin}^{-} \mathrm{CD} 117^{\text {lo }} \mathrm{GFP}^{+}$cells resulted in eosinophilia and clearance of worms. N. brasiliensis infection of YetCre13 mice or another reporter mouse strain in which human $\mathrm{CD} 4$ coding sequences were inserted into the $i l 13$ locus induced $\mathrm{YFP}^{+}$or human $\mathrm{CD}^{+}$cells, respectively, in the lung (Liang et al., 2012). Induction of $\mathrm{YFP}^{+}$ cells and eosinophilia were impaired in YetCre13 mice crossed with gata $^{\text {flox/flox }}$ mice, suggesting that sustained expression of IL-13 requires GATA3 (Liang et al., 2012).

\section{Th2-TYPE INNATE LYMPHOCYTES AND ALLERGIC INFLAMMATION}

Significant numbers of NH cells are induced in the lung upon influenza A virus infection (Chang et al., 2011; Monticelli et al., 2011). Influenza virus infection induces IL-33 in the lung and causes airway hypersensitivity (Chang et al., 2011; Le Goffic et al., 2011). illrl1 ${ }^{-1-}$ mice did not exhibit H3N1 influenza A virus infection-induced airway hypersensitivity while OVA-induced airway hypersensitivity was unaffected (Chang et al., 2011). However, $\mathrm{H} 3 \mathrm{~N} 1$ infection as well as intranasal administration of IL-33

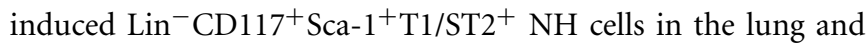
bronchoalveolar lavage fluid and this was also observed in rag2 $2^{-1-}$ mice. NH cells purified as $\mathrm{Lin}^{-}{ }^{-\mathrm{T} 1 / \mathrm{ST} 2}{ }^{+}$cells from IL-33-treated mice produced IL- 5 and IL-13 but not IL-4, IFN- $\gamma$, or IL17A after cultivation with IL-2, IL-33, or IL-2 + IL-33. il13-/- mice did not develop airway hypersensitivity or cellular infiltration upon $\mathrm{H} 3 \mathrm{~N} 1$ infection, but both responses were restored by adoptive transfer of

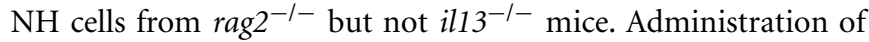
anti-CD90 mAb depleted NH cells in the lung and impaired airway hypersensitivity upon H3N1 infection (Chang et al., 2011), indicating that $\mathrm{NH}$ cells are responsible for airway hypersensitivity induced by $\mathrm{H} 3 \mathrm{~N} 1$ influenza virus infection. There is a caveat, however, in that anti-CD90 mAb also depletes NK cells in rag2-1mice. In addition, $\mathrm{NH}$ cells play a major role in airway hypersensitivity induced by glycolipid antigen (Kim et al., 2012) or papain (Halim et al., 2012). Similarly, nuocytes were reported to play a role in airway hypersensitivity induced by intranasal administration of IL-25 or IL-33 in il4/il13 dual reporter mice (Barlow et al., 2011).

Monticelli et al. (2011) and Halim et al. (2012) reported the presence of a small number of $\mathrm{NH}$ cells in the lung of naïve wild type and $\mathrm{rag}^{-1-}$ mice. A mouse has $2-3 \times 10^{4}$ lung $\mathrm{NH}$ cells which represent $0.4-1 \%$ of total live cells in the lung. Lung $\mathrm{NH}$ cells produced IL-5 and IL-13 when cultured with a combination of IL-2, IL-7, and IL-33. They produced minimal amounts of IL-17 and IL-22 in response to IL-23, confirming the difference between Th2-type innate lymphocytes and ROR $\gamma^{+}$LTi-related Th17-type innate lymphocytes (Monticelli et al., 2011). Lung NH cells express Id 2 but not ROR $\gamma$ as do FALC NH cells, and $i d 2^{-1-}$ mice lack lung NH cells as expected.

Increases in the number of lung $\mathrm{NH}$ cells were also observed upon intranasal infection with $\mathrm{H} 1 \mathrm{~N} 1$ influenza A virus (Monticelli et al., 2011). Depletion of NH cells in the lung by intraperitoneal injection of anti-CD90 mAb did not affect viral load but impaired lung functions such as blood oxygen saturation level and epithelial integrity. H1N1 infection-induced eosinophilia in the bronchoalveolar lavage fluid and the eosinophilia was reduced by anti-CD90 $\mathrm{mAb}$ treatment. Adoptive transfer of $\mathrm{Lin}^{-} \mathrm{CD} 25^{+} \mathrm{CD} 90^{+} \mathrm{T} 1 / \mathrm{ST} 2^{+} \mathrm{NH}$ cells isolated from the lung of CD90.1 (Thy-1.1) wild type mice into CD90.2 (Thy-1.2) congenic mice treated with anti-CD90.2 $\mathrm{mAb}$ restored the epithelial responses of the recipient mice. Administration of anti-T1/ST2 $\mathrm{mAb}$ reduced $\mathrm{NH}$ cell numbers and greatly impaired lung function upon $\mathrm{H} 1 \mathrm{~N} 1$ infection. Administration of IL-13 to anti-CD90 mAb-treated mice infected with $\mathrm{H} 1 \mathrm{~N} 1$ restored goblet cell hyperplasia but did not improve lung function or virus-induced morbidity and mortality, suggesting the presence of a factor(s) other than IL-13 involved in the maintenance of epithelial integrity. Among the cytokines produced by $\mathrm{NH}$ cells, amphiregulin was identified as a critical factor (Monticelli et al., 2011). Amphiregulin is involved in the remodeling and repair of epithelial injury (Dolinay et al., 2006; Enomoto et al., 2009; Fukumoto et al., 2010). Purified lung $\mathrm{NH}$ cells produce amphiregulin in response to IL$2+$ IL-7, and IL-33 further enhanced amphiregulin production induced by IL-2 + IL-7. Administration of amphiregulin restored lung function and epithelial integrity in anti-CD90-treated mice infected with H1N1 without inducing IL-5 or IL-13 (Monticelli et al., 2011), indicating that amphiregulin produced by IL-33activated NH cells plays a critical role in the process of repairing epithelial integrity after influenza virus infection.

\section{PROTEASE-INDUCED ALLERGIC RESPONSES AND IL-9 PRODUCING CELLS}

IL-9, another Th2 cytokine, is highly expressed in the lungs of asthmatic patients (Shimbara et al., 2000; Erpenbeck et al., 2003) and anti-IL-9 mAb is currently in clinical trial for atopic diseases (White et al., 2009). In mice, overexpression of IL-9 in the lung induces an asthma-like phenotype in an IL-13-dependent manner (Temann et al., 1998, 2002, 2007) and blocking of IL-9 reduces airway hypersensitivity (Kung et al., 2001; Cheng et al., 2002). IL-9 induces mucous production, goblet cell hyperplasia, and other features of airway remodeling (Townsend et al., 2000; Kearley et al., 2011), effects shared by IL-13 via goblet cell hyperplasia (Wynn, 2003) and IL-5 via eosinophilia (Cho et al., 2004). These results collectively suggest the presence of an IL-9/IL-13 axis in the lung. On the other hand, IL-9 may not play a critical role in some forms of asthmatic diseases because the absence of IL- 9 shows little effect on antigen-induced pulmonary inflammation or airway hypersensitivity (McMillan et al., 2002).

Papain can cause occupational asthma (Novey et al., 1979) and has been used in allergic models because it has a strong 
adjuvant activity in the induction of asthma-like symptoms and airway hypersensitivity (Oboki et al., 2010; Wang et al., 2010). Halim et al. (2012) demonstrated that $\mathrm{NH}$ cells play a critical role in protease allergen-induced airway inflammation. NH cells induced by papain do not respond to IL-33 alone and require IL2 or IL-7 along with IL-33 to produce IL-5 and IL-13 (Halim et al., 2012). Papain-induced transient production of IL-9 in the lung (Tan et al., 2010), raising the possible involvement of an IL-9/IL-13 axis in airway hypersensitivity induced by innate lymphocytes. To examine the source of IL-9, IL-9 fate mapping mice were generated by crossing il9-Cre mice and rosa-YFP mice (Wilhelm et al., 2011). Intranasal challenge with papain induces Th2-type responses with production of IL-4, IL-5, IL-9, and IL13 and the appearance of IL- $9^{\mathrm{fm}}+$ cells in bronchoalveolar lavage fluid, most of which are $\mathrm{Lin}^{-} \mathrm{CD} 45^{+} \mathrm{CD} 90^{+}$cells. These cells did not express CD117 or CD127 but expressed heterogeneous levels of Sca-1, CD25, T1/ST2, and MHC class II, implying that these cells are distinct from NH cells or nuocytes, although it is possible that papain stimulation changes the surface phenotype of these cells. Stimulation with PMA and ionomycin in vitro induced the production of IL- 5 and IL-13 but not IL- 4 or IL9 by IL- $9^{\mathrm{fm}}+$ cells. Papain-induced $\mathrm{Lin}^{-} \mathrm{CD} 90^{+} \mathrm{CD} 25^{+} \mathrm{IL}-9^{\mathrm{fm}+}$ cells responded to IL-2 but not to IL-25, IL-33, or TSLP to produce IL-9. In addition, TLR ligands did not induce IL-9 production by these cells. Intranasal administration of IL-33 also induced IL- $9^{\mathrm{fm}}+$ cells, which were similar to those induced by papain.

Papain-induced IL-9 production in the lung was absent in $\gamma c^{-/-}$rag $2^{-1-}$ mice, suggesting that innate lymphocytes are the source of IL-9. In fact, intratracheal transfer of $\mathrm{Lin}^{-} \mathrm{CD} 90^{+}$cells isolated from papain-challenged mice into $\gamma \mathrm{c}^{-1-} \mathrm{rag} 2^{-1-}$ mice followed by intranasal challenge with papain restored the production of IL-5, IL-9, and IL-13 (Wilhelm et al., 2011). Papain-treated mice produced IL-4, IL-5, IL-6, IL-9, and IL-13 in the lung but administration of anti-IL-2 mAb reduced only IL-9 production. Papain-treated rag1 $1^{-/-}$mice produced lower amounts of IL-9 than wild type mice but produced IL-9 at a level similar to wild type mice when IL-2 was intranasally administered after papain challenge. Intranasal administration of IL-2 alone showed no effect. Papain-induced IL-9 producing cells were mostly $\mathrm{Lin}^{-} \mathrm{CD} 90^{+}$ cells, which also produce IL-13. These results collectively indicate that innate lymphocytes cooperate with $\mathrm{T}$ and/or B cells and that $\mathrm{T}$ and/or B cell-derived IL-2 plays a positive role in IL-9 production by innate lymphocytes.

\section{Th2-TYPE INNATE LYMPHOCYTES IN HUMANS}

Th2-type innate lymphocytes are also observed in humans. The presence of innate lymphocytes similar to $\mathrm{NH}$ cells has been reported in human gut, lung, mesentery, and blood (Moro et al., 2010; Mjösberg et al., 2011; Monticelli et al., 2011). FALC and $\mathrm{Lin}^{-} \mathrm{CD} 117^{+} \mathrm{CD} 127^{+}$cells were observed in human mesentery (Moro et al., 2010). Human lung and bronchoalveolar lavage fluid also have a similar $\mathrm{Lin}^{-} \mathrm{CD} 25^{+} \mathrm{CD} 127^{+} \mathrm{T} 1 / \mathrm{ST} 2^{+}$population (Monticelli et al., 2011). CRTH2 was identified as a valuable marker for human $\mathrm{NH}$ cells (Mjösberg et al., 2011). $\mathrm{CD} 45^{\mathrm{hi}} \mathrm{CD} 127^{+} \mathrm{CRTH}_{2}{ }^{+}$cells produced IL-13 in response to IL- + IL-25 and IL-2 + IL-33. CD $45^{\text {hi }} \mathrm{CD} 127^{+} \mathrm{CRTH} 2^{+}$cells expressed a low level of $\operatorname{ROR} \gamma$, which is different from mouse $\mathrm{NH}$ cells. It should be noted that $\mathrm{ROR} \gamma^{+}$LTi cells are able to produce IL-5 and IL-13 in addition to IL-22 in response to TLR2 ligands (Crellin et al., 2010b), implying that NH cells and LTi-related cells share some characteristics in humans. Peripheral blood contains $\mathrm{Lin}^{-} \mathrm{CD} 45^{+} \mathrm{CD} 127^{+} \mathrm{CRTH} 2^{+}$cells expressing CD7, CD161, CD62L, and CD25 but lacking NKp44 and MHC class II. Lin $^{-} \mathrm{CD} 45^{+} \mathrm{CD} 127^{+}$cells produce a variety of cytokines including TNF $\alpha$, IFN- $\gamma$, IL-22 IL-17, IL-13, and IL2 but only $\mathrm{Lin}^{-} \mathrm{CD} 45^{+} \mathrm{CD} 127^{+} \mathrm{CRTH} 2^{+}$cells produce IL- 13 . Thus, human LTi and Th2-type innate lymphocytes share similar characteristics.

Rhinosinusitis patients with nasal polyps have more il5 and ill3 mRNAs than those without nasal polyps (Van Bruaene et al., 2008). Nasal tissue from the nasal polyps of patients with chronic rhinosinusitis has an increased number of $\mathrm{Lin}^{-} \mathrm{CD} 45^{+} \mathrm{CD} 127^{+} \mathrm{CD} 161^{+} \mathrm{CRTH} 2^{+}$cells, which do not express ROR $\gamma$ (Mjösberg et al., 2011). Treatment of lamina propria cells from ulcerative colitis patients with anti-CD161 reduced IL-5 and IL-13 expression (Fuss et al., 2004) and it was proposed that the depletion of NKT cells resulted in the reduction of Th2 cytokines (Fuss et al., 2004). However, it is also possible that the loss of $\mathrm{Lin}^{-} \mathrm{CD} 45^{+} \mathrm{CD} 127^{+} \mathrm{CRTH} 2^{+}$cells is the cause of reduced Th2 cytokine production because these cells also express CD161.

\section{PERSPECTIVES}

In this article we have summarized current knowledge regarding various innate lymphocyte subsets by focusing on the most recently identified Th2-type innate lymphocyte subsets. As discussed here, Th2-type innate lymphocytes seem to comprise more than one type of cells. There are differences between $\mathrm{NH}$ cells and nuocytes/Ih2 cells in migration to lymph nodes, surface phenotypes, and cytokine responsiveness. It is likely that there are at least two distinct populations within Th2-type innate lymphocytes but it is also possible that there is plasticity within Th2-type innate lymphocytes as is true for ROR $\gamma^{+}$LTi-related innate lymphocytes. It should be noted that, in many experiments, cells are detected by reporter gene expression after treatment of mice with cytokines, viruses, and papain. There is a caveat that such treatment changes the naïve stage surface phenotypes of cells and it is critical to analyze innate lymphocytes in naïve mice and examine the changes in characteristics after activation.

Innate immune cells of myeloid origin express a variety of toll-like receptors and lectins that respond to microbe-derived substances (Kawai and Akira, 2010). In contrast, cNK cells and ROR $\gamma^{+}$LTi-related cells express a limited number of toll-like receptors (Crellin et al., 2010b). It is intriguing that Th2-type innate lymphocytes do not respond to toll-like receptor ligands but respond only to cytokines. It will be of interest to determine whether Th2-type innate lymphocytes directly respond to microbe-derived substances.

Distinct types of Th cells are involved in the pathophysiology of various diseases such as inflammatory, allergic, and autoimmune diseases. It is likely that innate lymphocytes are involved in the pathophysiology of various diseases via the production of distinct sets of cytokines (Figure 1). Th2-type innate lymphocytes are 
likely involved in innate immune responses resulting in the pathophysiology of allergic diseases such as asthma. It will be of interest to study how innate lymphocytes are involved in disease onset and progression and whether perturbation of innate lymphocytes can lead to new treatments for human diseases. Finally, the presence of $\mathrm{NH}$ cells in FALC localized in adipose tissue suggests that $\mathrm{NH}$ cells have regulatory functions in the homeostasis of adipose tissues, which will be an important subject for future studies.

\section{REFERENCES}

Angkasekwinai, P., Park, H., Wang, Y. H., Wang, Y. H., Chang, S. H., Corry, D. B., Liu, Y. J., Zhu, Z., and Dong, C. (2007). Interleukin 25 promotes the initiation of proallergic type 2 responses. J. Exp. Med. 204, 1509-1517.

Arase, H., and Lanier, L. L. (2004). Specific recognition of virus-infected cells by paired NK receptors. Rev. Med. Virol. 14, 83-93.

Aujla, S. J., Chan, Y. R., Zheng, M., Fei, M., Askew, D. J., Pociask, D. A., Reinhart, T. A., McAllister, F., Edeal, J., Gaus, K., Husain, S., Kreindler, J. L., Dubin, P. J., Pilewski, J. M., Myerburg, M. M., Mason, C. A., Iwakura, Y., and Kolls, J. K. (2008). IL-22 mediates mucosal host defense against Gram-negative bacterial pneumonia. Nat. Med. 14, 275-281.

Barlow, J. L., Bellosi, A., Hardman, C. S, Drynan, L. F., Wong, S. H., Cruickshank, J. P., and McKenzie, A. N. (2011). Innate IL-13producing nuocytes arise during allergic lung inflammation and contribute to airways hyperreactivity. J. Allergy Clin. Immunol. 129, 191-198.

Bartemes, K. R., Iijima, K., Kobayashi, T., Kephart, G. M., McKenzie, A. N., and Kita, H. (2012). IL-33responsive lineage-CD25 ${ }^{+} \mathrm{CD} 44 \mathrm{hi}$ lymphoid cells mediate innate type 2 immunity and allergic inflammation in the lungs. J. Immunol. 188, 1503-1513.

Biron, C. A., Nguyen, K. B., Pien, G. C., Cousens, L. P., and SalazarMather, T. P. (1999). Natural killer cells in antiviral defense: function and regulation by innate cytokines. Annu. Rev. Immunol. 17, 189-220.

Brickshawana, A., Shapiro, V. S., Kita, H., and Pease, L. R. (2011). Lineage-

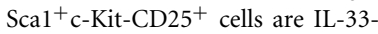
responsive type 2 innate cells in the mouse bone marrow. J. Immunol. 187, 5795-5804.

Brunner, S. M., Schiechl, G., Falk, W., Schlitt, H. J., Geissler, E. K., and Fichtner-Feigl, S. (2011). Interleukin-33 prolongs allograft survival during chronic cardiac rejection. Transpl. Int. 24, 1027-1039.

Buonocore, S., Ahern, P. P., Uhlig, H. H., Ivanov, I. I., Littman, D. R., Maloy, K. J., and Powrie, F. (2010). Innate lymphoid cells drive interleukin-23-dependent innate intestinal pathology. Nature 464, 1371-1375.

Cella, M., Fuchs, A., Vermi, W., Facchetti, F., Otero, K., Lennerz, J. K., Doherty, J. M., Mills, J. C., and Colonna, M. (2009). A human natural killer cell subset provides an innate source of IL-22 for mucosal immunity. Nature 457, $722-725$.

Chang, Y. J., Kim, H. Y., Albacker, L. A., Baumgarth, N., McKenzie, A. N., Smith, D. E., Dekruyff, R. H., and Umetsu, D. T. (2011). Innate lymphoid cells mediate influenza-induced airway hyperreactivity independently of adaptive immunity. Nat. Immunol. 12, 631-638.

Cheng, G., Arima, M., Honda, K., Hirata, H., Eda, F., Yoshida, N., Fukushima, F., Ishii, Y., and Fukuda, T. (2002). Anti-interleukin-9 antibody treatment inhibits airway inflammation and hyperreactivity in mouse asthma model. Am. J. Respir. Crit. Care Med. 166, 409-416.

Cho, J. Y., Miller, M., Baek, K. J., Han, J. W., Nayar, J., Lee, S. Y., McElwain, K., McElwain, S., Friedman, S., and Broide, D. H. (2004). Inhibition of airway remodeling in IL-5-deficient mice. J. Clin. Invest. 113, 51-60.

Cooper, M. A., Fehniger, T. A., Turner, S. C., Chen, K. S., Ghaheri, B. A., Ghayur, T., Carson, W. E., and Caligiuri, M. A. (2001). Human natural killer cells: a unique innate immunoregulatory role for the CD56bright subset. Blood 97, 146-151.

Crellin, N. K., Trifari, S., Kaplan, C. D., Cupedo, T., and Spits, H. (2010a). Human NKp $44^{+} \mathrm{IL}_{-} 22^{+}$cells and LTi-like cells constitute a stable $\mathrm{RORC}^{+}$lineage distinct from conventional natural killer cells. J. Exp. Med. 207, 281-290.

\section{ACKNOWLEDGMENTS}

We thank our collaborators and members of our laboratory. This work was supported by a Grant-in-Aid for Young Scientist (A) (22689013 to Kazuyo Moro) and a Grant-in-Aid for Scientific Research (S) (22229004 to Shigeo Koyasu) from the Japan Society for the Promotion of Science, and Precursory Research for Embryonic Science and Technology (PRESTO to Kazuyo Moro) from the Japan Science and Technology Agency.

Crellin, N. K., Trifari, S., Kaplan, C. D., Satoh-Takayama, N., Di Santo, J. P., and Spits, H. (2010b). Regulation of cytokine secretion in human CD $127^{+}$LTi-like innate lymphoid cells by Toll-like receptor 2. Immunity 33, 752-764.

Cupedo, T., Crellin, N. K., Papazian, N., Rombouts, E. J, Weijer, K., Grogan, J. L., Fibbe, W. E., Cornelissen, J. J., and Spits, H. (2009). Human fetal lymphoid tissue-inducer cells are interleukin 17-producing precursors to $\mathrm{RORC}^{+} \mathrm{CD}^{-} 27^{+}$natural killer-like cells. Nat. Immunol. 10 , 66-74.

De Luca, A., Zelante, T., D’Angelo, C. Zagarella, S., Fallarino, F., Spreca, A., Iannitti, R. G., Bonifazi, P., Renauld, J. C., Bistoni, F., Puccetti, P., and Romani, L. (2010). IL-22 defines a novel immune pathway of antifungal resistance. Mucosal Immunol. 3, 361-373.

Dolinay, T., Kaminski, N., Felgendreher, M., Kim, H. P., Reynolds, P., Watkins, S. C., Karp, D., Uhlig, S., and Choi, A M. (2006). Gene expression profiling of target genes in ventilator-induced lung injury. Physiol. Genomics 26, 68-75.

Eberl, G., Marmon, S., Sunshine, M. J., Rennert, P. D., Choi, Y., and Littman, D. R. (2004). An essential function for the nuclear receptor $\operatorname{ROR} \gamma(\mathrm{t})$ in the generation of fetal lymphoid tissue inducer cells. Nat. Immunol. 5 , 64-73.

Eisenbarth, S. C., Piggott, D. A., Huleatt, J. W., Visintin, I., Herrick, C. A., and Bottomly, K. (2002). Lipopolysaccharide-enhanced, toll-like receptor 4-dependent $\mathrm{T}$ helper cell type 2 responses to inhaled antigen. J. Exp. Med. 196, 1645-1651.

Enomoto, Y., Orihara, K., Takamasu, T., Matsuda, A., Gon, Y., Saito, H., Ra, C., and Okayama, Y. (2009). Tissue remodeling induced by hypersecreted epidermal growth factor and amphiregulin in the airway after an acute asthma attack. J. Allergy Clin. Immunol. 124, 913-920.

Erpenbeck, V. J., Hohlfeld, J. M., Volkmann, B., Hagenberg, A., Geldmacher, H., Braun, A., and Krug,
N. (2003). Segmental allergen challenge in patients with atopic asthma leads to increased IL-9 expression in bronchoalveolar lavage fluid lymphocytes. J. Allergy Clin. Immunol. 111, 1319-1327.

Fallon, P. G., Ballantyne, S. J., Mangan, N. E., Barlow, J. L., Dasvarma, A., Hewett, D. R., McIlgorm, A., Jolin, H. E., and McKenzie, A. N. (2006). Identification of an interleukin (IL)25-dependent cell population that provides IL-4, IL-5, and IL-13 at the onset of helminth expulsion. J. Exp. Med. 203, 1105-1116.

Fort, M. M., Cheung, J., Yen, D., Li, J., Zurawski, S. M., Lo, S., Menon, S., Clifford, T., Hunte, B., Lesley, R., Muchamuel, T., Hurst, S. D. Zurawski, G., Leach, M. W., Gorman, D. M., and Rennick, D. M. (2001). IL-25 induces IL-4, IL-5, and IL13 and Th2-associated pathologies in vivo. Immunity 15, 985-995.

Freud, A. G., Yokohama, A., Becknell, B., Lee, M. T., Mao, H. C., Ferketich, A. K., and Caligiuri, M. A. (2006). Evidence for discrete stages of human natural killer cell differentiation in vivo. J. Exp. Med. 203, 1033-1043.

Fukumoto, J., Harada, C., Kawaguchi, T. Suetsugu, S., Maeyama, T., Inoshima I., Hamada, N., Kuwano, K., and Nakanishi, Y. (2010). Amphiregulin attenuates bleomycin-induced pneumopathy in mice. Am. J. Physiol. Lung Cell. Mol. Physiol. 298, L131-L138.

Fuss, I. J., Heller, F., Boirivant, M., Leon, F., Yoshida, M., FichtnerFeigl, S., Yang, Z., Exley, M., Kitani, A., Blumberg, R. S., Mannon, P., and Strober, W. (2004). Nonclassical CD1d-restricted NK T cells that produce IL-13 characterize an atypical Th2 response in ulcerative colitis. J. Clin. Invest. 113, 1490-1497.

Gascoyne, D. M., Long, E., VeigaFernandes, H., de Boer, J., Williams O., Seddon, B., Coles, M., Kioussis, D., and Brady, H. J. (2009). The basic leucine zipper transcription factor E4BP4 is essential for natural killer cell development. Nat. Immunol. 10, 1118-1124. 
Gessner, A., Mohrs, K., and Mohrs, M. (2005). Mast cells, basophils, and eosinophils acquire constitutive IL-4 and IL-13 transcripts during lineage differentiation that are sufficient for rapid cytokine production. J. Immunol. 174, 1063-1072.

Grünig, G., Warnock, M., Wakil, A. E., Venkayya, R., Brombacher, F., Rennick, D. M., Sheppard, D., Mohrs, M., Donaldson, D. D., Locksley, R. M., and Corry, D. B. (1998). Requirement for IL-13 independently of IL4 in experimental asthma. Science 282, 2261-2263.

Halim, T. Y. F., Krauß, R. H., Sun, A. C., and Takei, F. (2012). Lung natural helper cells are a critical source of Th2 cytokines in protease allergen induced airway inflammation. Immunity 36, 451-463.

Happel, K. I., Dubin, P. J., Zheng, M., Ghilardi, N., Lockhart, C., Quinton, L. J., Odden, A. R., Shellito, J. E., Bagby, G. J., Nelson, S., and Kolls, J. K. (2005). Divergent roles of IL23 and IL-12 in host defense against Klebsiella pneumoniae. J. Exp. Med. 202, 761-769.

Ho, L. H., Ohno, T., Oboki, K., Kajiwara, N., Suto, H., Iikura, M., Okayama, Y., Akira, S., Saito, H., Galli, S. J., and Nakae, S. (2007). IL-33 induces IL13 production by mouse mast cells independently of IgE-FceRI signals. J. Leukoc. Biol. 82, 1481-1490.

Holgate, S. T., and Polosa, R. (2008). Treatment strategies for allergy and asthma. Nat. Rev. Immunol. 8, 218-230.

Hotez, P. J., Brooker, S., Bethony, J. M., Bottazzi, M. E., Loukas, A., and Xiao, S. (2004). Hookworm infection. N. Engl. J. Med. 351, 799-807.

Hughes, T., Becknell, B., McClory, S., Briercheck, E., Freud, A. G., Zhang, X., Mao, H., Nuovo, G., Yu, J., and Caligiuri, M. A. (2009). Stage 3 immature human natural killer cells found in secondary lymphoid tissue constitutively and selectively express the TH 17 cytokine interleukin-22. Blood 113, 4008-4010.

Humphreys, N. E., Xu, D., Hepworth, M. R., Liew, F. Y., and Grencis, R. K. (2008). IL-33, a potent inducer of adaptive immunity to intestinal nematodes. J. Immunol. 180, 2443-2449.

Hurst, S. D., Muchamuel, T., Gorman, D. M., Gilbert, J. M., Clifford, T., Kwan, S., Menon, S., Seymour, B., Jackson, C., Kung, T. T., Brieland, J. K., Zurawski, S. M., Chapman, R. W., Zurawski, G., and Coffman, R. L. (2002). New IL-17 family members promote Th1 or Th2 responses in the lung: in vivo function of the novel cytokine IL-25. J. Immunol. 169, 443-453.

Igarashi, H., Gregory, S. C., Yokota, T., Sakaguchi, N., and Kincade, P. W. (2002). Transcription from the RAG1 locus marks the earliest lymphocyte progenitors in bone marrow. Immunity 17, 117-130.

Ikutani, M., Yanagibashi, T., Ogasawara, M., Tsuneyama, K., Yamamoto, S., Hattori, Y., Kouro, T., Itakura, A., Nagai, Y., Takaki, S., and Takatsu, K. (2012). Identification of innate IL5 -producing cells and their role in lung eosinophil regulation and antitumor immunity. J. Immunol. 188, 703-713.

Kamizono, S., Duncan, G. S., Seidel, M. G., Morimoto, A., Hamada, K., Grosveld, G., Akashi, K., Lind, E. F., Haight, J. P., Ohashi, P. S., Look, A. T., and Mak, T. W. (2009). Nfil3/E4bp4 is required for the development and maturation of NK cells in vivo. J. Exp. Med. 206, 2977-2986.

Kawai, T., and Akira, S. (2010). The role of pattern-recognition receptors in innate immunity: update on toll-like receptors. Nat. Immunol. 11, 373-384.

Kearley, J., Erjefalt, J. S., Andersson, C., Benjamin, E., Jones, C. P. Robichaud, A., Pegorier, S., Brewah, Y., Burwell, T. J., Bjermer, L., Kiener, P. A., Kolbeck, R., Lloyd, C. M., Coyle, A. J., and Humbles, A. A. (2011). IL-9 governs allergeninduced mast cell numbers in the lung and chronic remodeling of the airways. Am. J. Respir. Crit. Care Med. 183, 865-875.

Kennedy, M. K., Glaccum, M., Brown, S. N., Butz, E. A., Viney, J. L., Embers, M., Matsuki, N., Charrier, K., Sedger, L., Willis, C. R., Brasel, K., Morrissey, P. J., Stocking, K., Schuh, J. C., Joyce, S., and Peschon, J. J. (2000). Reversible defects in natural killer and memory CD8 $\mathrm{T}$ cell lineages in interleukin 15deficient mice. J. Exp. Med. 191, 771-780.

Kim, H. Y., Chang, Y. J., Subramanian, S., Lee, H. H., Albacker, L. A., Matangkasombut, P., Savage, P. B., McKenzie, A. N., Smith, D. E., Rottman, J. B., Dekruyff, R. H., and Umetsu, D. T. (2012). Innate lymphoid cells responding to IL-33 mediate airway hyperreactivity independently of adaptive immunity. $J$. Allergy Clin. Immunol. 129, 216-217.

Kondo, Y., Yoshimoto, T., Yasuda, K. Futatsugi-Yumikura, S., Morimoto, M., Hayashi, N., Hoshino, T., Fujimoto, J., and Nakanishi, K. (2008).
Administration of IL-33 induces airway hyperresponsiveness and goblet cell hyperplasia in the lungs in the absence of adaptive immune system. Int. Immunol. 20, 791-800.

Kopf, M., Le Gros, G., Bachmann, M. Lamers, M. C., Bluethmann, H. and Köhler, G. (1993). Disruption of the murine IL-4 gene blocks Th2 cytokine responses. Nature 362 , 245-248.

Koyasu, S., Moro, K., Tanabe, M., and Takeuchi, T. (2010). Natural helper cells: a new player in the innate immune response against helminth infection. Adv. Immunol. 108 21-44.

Kung, T. T., Luo, B., Crawley, Y., Garlisi, C. G., Devito, K., Minnicozzi, M., Egan, R. W., Kreutner, W., and Chapman, R. W. (2001). Effect of antimIL-9 antibody on the development of pulmonary inflammation and airway hyperresponsiveness in allergic mice. Am. J. Respir. Cell Mol. Biol. 25, 600-605.

Kurebayashi, S., Ueda, E., Sakaue, M., Patel, D. D., Medvedev, A., Zhang, F., and Jetten, A. M. (2000). Retinoidrelated orphan receptor $\gamma(\operatorname{ROR} \gamma)$ is essential for lymphoid organogenesis and controls apoptosis during thymopoiesis. Proc. Natl. Acad. Sci. U.S.A. 97, 10132-10127.

Larché, M., Robinson, D. S., and Kay, A. B. (2003). The role of T lymphocytes in the pathogenesis of asthma. J. Allergy Clin. Immunol. 111, 450-463.

Le Goffic, R., Arshad, M. I., Rauch, M. L'helgoualc'h, A., Delmas, B., PiquetPellorce, C., and Samson, M. (2011) Influenza virus infection induces IL33 in mouse lungs. Am. J. Respir. Cell. Mol. Biol. 45, 1125-1132.

Liang, H. E., Reinhardt, R. L., Bando, J. K., Sullivan, B. M., Ho, I. C., and Locksley, R. M. (2012). Divergent expression patterns of IL-4 and IL13 define unique functions in allergic immunity. Nat. Immunol. 13 58-66.

Lochner, M., Peduto, L., Cherrier, M., Sawa, S., Langa, F., Varona, R., Riethmacher, D., Si-Tahar, M., Di Santo, J. P., and Eberl, G. (2008). In vivo equilibrium of proinflammatory IL$17^{+}$and regulatory IL- $10^{+}$Foxp3 $3^{+}$ ROR $\gamma \mathrm{t}^{+} \mathrm{T}$ cells. J. Exp. Med. 205, 1381-1393.

Louten, J., Rankin, A. L., Li, Y., Murphy, E. E., Beaumont, M., Moon, C., Bourne, P., McClanahan, T. K. Pflanz, S., and de Waal Malefyt, R. (2011). Endogenous IL-33 enhances Th2 cytokine production and $\mathrm{T}$ cell responses during allergic airway inflammation. Int. Immunol. 23 , 307-315.
Luci, C., Reynders, A., Ivanov, I. I., Cognet, C., Chiche, L., Chasson, L., Hardwigsen, J., Anguiano, E., Banchereau, J., Chaussabel, D., Dalod, M., Littman, D. R., Vivier, E., and Tomasello, E. (2009). Influence of the transcription factor ROR $\gamma \mathrm{t}$ on the development

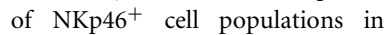
gut and skin. Nat. Immunol. 10, 75-82.

Maizels, R. M., Pearce, E. J., Artis, D., Yazdanbakhsh, M., and Wynn, T. A. (2009). Regulation of pathogenesis and immunity in helminth infections. J. Exp. Med. 206, 2059-2066.

McKenzie, G. J., Bancroft, A., Grencis, R. K., and McKenzie, A. N. (1998) A distinct role for interleukin13 in Th2-cell-mediated immune responses. Curr. Biol. 8, 339-342.

McKenzie, G. J., Fallon, P. G., Emson, C. L., Grencis, R. K., and McKenzie, A. N. (1999). Simultaneous disruption of interleukin (IL)-4 and IL-13 defines individual roles in $\mathrm{T}$ helper cell type 2-mediated responses. J. Exp. Med. 189, 1565-1572.

McMillan, S. J., Bishop, B., Townsend, M. J., McKenzie, A. N., and Lloyd C. M. (2002). The absence of interleukin 9 does not affect the development of allergen-induced pulmonary inflammation nor airway hyperreactivity. J. Exp. Med. 195, 51-57.

Mebius, R. E. (2003). Organogenesis of lymphoid tissues. Nat. Rev. Immunol. 3, 292-303.

Mebius, R. E., Miyamoto, T., Christensen, J., Domen, J., Cupedo, T., Weissman, I. L., and Akashi, K. (2001). The fetal liver counterpart of adult common lymphoid progenitors gives rise to all lymphoid lineages, $\mathrm{CD} 45^{+} \mathrm{CD} 4{ }^{+} \mathrm{CD} 3$ - cells, as well as macrophages. J. Immunol. 166, 6593-6601.

Mebius, R. E., Rennert, P., and Weissman, I. L. (1997). Developing lymph nodes collect $\mathrm{CD} 4{ }^{+} \mathrm{CD} 3-\mathrm{LT} \beta^{+}$cells that can differentiate to APC, NK cells, and follicular cells but not $\mathrm{T}$ or B cells. Immunity 7, 493-504

Meier, D., Bornmann, C., Chappaz, S., Schmutz, S., Otten, L. A., Ceredig, R., Acha-Orbea, H., and Finke, D. (2007). Ectopic lymphoid-organ development occurs through interleukin 7-mediated enhanced survival of lymphoid-tissue-inducer cells. Immunity 26, 643-654.

Min, B., Prout, M., Hu-Li, J., Zhu, J., Jankovic, D., Morgan, E. S., Urban, J. F. Jr, Dvorak, A. M., Finkelman, F. D., LeGros, G., and Paul, W. E. (2004). Basophils produce IL-4 and 
accumulate in tissues after infection with a Th2-inducing parasite. J. Exp. Med. 200, 507-517.

Mjösberg, J. M., Trifari, S., Crellin, N. K., Peters, C. P., van Drunen, C. M., Piet, B., Fokkens, W. J., Cupedo, T., and Spits, H. (2011). Human IL-25- and IL-33-responsive type 2 innate lymphoid cells are defined by expression of CRTH2 and CD161. Nat. Immunol. 12, 1055-1062.

Mohrs, K., Wakil, A. E., Killeen, N., Locksley, R. M., and Mohrs, M. (2005). A two-step process for cytokine production revealed by IL4 dual-reporter mice. Immunity 2, 419-429.

Mohrs, M., Shinkai, K., Mohrs, K., and Locksley, R. M. (2001). Analysis of type 2 immunity in vivo with a bicistronic IL-4 reporter. Immunity 15, 303-311.

Monticelli, L. A., Sonnenberg, G. F. Abt, M. C., Alenghat, T., Ziegler, C. G., Doering, T. A., Angelosanto, J. M., Laidlaw, B. J., Yang, C. Y., Sathaliyawala, T., Kubota, M., Turner, D., Diamond, J. M., Goldrath, A. W., Farber, D. L., Collman, R. G., Wherry, E. J., and Artis, D. (2011). Innate lymphoid cells promote lung-tissue homeostasis after infection with influenza virus. Nat. Immunol. 12, 1045-1054.

Moro, K., Yamada, T., Tanabe, M., Takeuchi, T., Ikawa, T., Kawamoto, H., Furusawa, J., Ohtani, M., Fujii, H., and Koyasu, S. (2010). Innate production of $\mathrm{TH} 2$ cytokines by adipose tissue-associated $\mathrm{c}-\mathrm{Kit}^{+} \mathrm{Sca}-$ $1^{+}$lymphoid cells. Nature 463 540-544.

Neill, D. R., Wong, S. H., Bellosi, A., Flynn, R. J., Daly, M., Langford, T. K., Bucks, C., Kane, C. M., Fallon, P. G., Pannell, R., Jolin, H. E., and McKenzie, A. N. (2010). Nuocytes represent a new innate effector leukocyte that mediates type- 2 immunity. Nature 464, 1367-1370.

Novey, H. S., Marchioli, L. E., Sokol, W. N., and Wells, I. D. (1979). Papaininduced asthma - physiological and immunological features. J. Allergy Clin. Immunol. 63, 98-103.

Oboki, K., Ohno, T., Kajiwara, N., Arae, K., Morita, H., Ishii, A., Nambu, A., Abe, T., Kiyonari, H., Matsumoto, K., Sudo, K., Okumura, K., Saito, H., and Nakae, S. (2010). IL-33 is a crucial amplifier of innate rather than acquired immunity. Proc. Natl. Acad. Sci. U.S.A. 107, 18581-18586.

Perrigoue, J. G., Marshall, F. A., and Artis, D. (2008). On the hunt for helminths: innate immune cells in the recognition and response to helminth parasites. Cell. Microbiol. 10, 1757-1764.

Perrigoue, J. G., Saenz, S. A., Siracusa M. C., Allenspach, E. J., Taylor, B. C., Giacomin, P. R., Nair, M. G., Du, Y., Zaph, C., van Rooijen, N., Comeau, M. R., Pearce, E. J., Laufer, T. M., and Artis, D. (2009). MHC class II-dependent basophil-CD4 ${ }^{+}$ $\mathrm{T}$ cell interactions promote $\mathrm{TH} 2$ cytokine-dependent immunity. Nat. Immunol. 10, 697-705.

Possot, C., Schmutz, S., Chea, S., Boucontet, L., Louise, A., Cumano A., and Golub, R. (2011). Notch signaling is necessary for adult, but not fetal, development of ROR $\gamma \mathrm{t}^{+}$innate lymphoid cells. Nat. Immunol. 12, 949-958.

Price, A. E., Liang, H. E., Sullivan, B. M., Reinhardt, R. L., Eisley, C. J., Erle, D. J., and Locksley, R. M. (2010). Systemically dispersed innate IL-13expressing cells in type 2 immunity. Proc. Natl. Acad. Sci. U.S.A. 107, 11489-11494.

Ranson, T., Vosshenrich, C. A., Corcuff, E., Richard, O., Müller, W., and Di Santo, J. P. (2003). IL-15 is an essential mediator of peripheral NK-cell homeostasis. Blood 101, 4887-4893.

Reynders, A., Yessaad, N., Vu Manh, T. P. Dalod, M., Fenis, A., Aubry, C., Nikitas, G., Escalière, B., Renauld, J. C., Dussurget, O., Cossart, P., Lecuit, M., Vivier, E., and Tomasello, E. (2011). Identity, regulation and in vivo function of gut $\mathrm{NKp} 46^{+} \mathrm{ROR} \gamma \mathrm{t}^{+}$and $\mathrm{NKp} 46^{+} \mathrm{ROR} \gamma \mathrm{t}-$ lymphoid cells. EMBO J. 30, 2934-2947.

Ribeiro, V. S., Hasan, M., Wilson, A., Boucontet, L., Pereira, P., LesjeanPottier, S., Satoh-Takayama, N., Di Santo, J. P., and Vosshenrich, C. A. (2010). Cutting edge: thymic NK cells develop independently from $\mathrm{T}$ cell precursors. J. Immunol. 185, 4993-4997.

Saenz, S. A., Siracusa, M. C., Perrigoue, J. G., Spencer, S. P., Urban, J. F. Jr., Tocker, J. E., Budelsky, A. L., Kleinschek, M. A., Kastelein, R. A., Kambayashi, T., Bhandoola, A., and Artis, D. (2010). IL25 elicits a multipotent progenitor cell population that promotes $\mathrm{TH} 2$ cytokine responses. Nature 464, 1362-1366.

Saenz, S. A., Taylor, B. C., and Artis, D. (2008). Welcome to the neighborhood: epithelial cellderived cytokines license innate and adaptive immune responses at mucosal sites. Immunol. Rev. 226, 172-190.

Sanos, S. L., Bui, V. L., Mortha A., Oberle, K., Heners, C., Johner, C., and Diefenbach, A. (2009). ROR $\gamma \mathrm{t}$ and commensal microflora are required for the differentiation of mucosal interleukin 22-producing NKp46 ${ }^{+}$cells. Nat. Immunol. 10 83-91.

Satoh-Takayama, N., Lesjean-Pottier, S., Vieira, P., Sawa, S., Eberl, G., Vosshenrich, C. A., and Di Santo, J. P. (2010). IL-7 and IL-15 independently program the differentiation of intestinal CD3-NKp46 ${ }^{+}$cell subsets from Id2-dependent precursors. J. Exp. Med. 207, 273-280.

Satoh-Takayama, N., Vosshenrich, C. A. Lesjean-Pottier, S., Sawa, S., Lochner M., Rattis, F., Mention, J. J., Thiam, K., Cerf-Bensussan, N., Mandelboim, O., Eberl, G., and Di Santo, J. P. (2008). Microbial flora drives interleukin 22 production in intestinal NKp $46^{+}$cells that provide innate mucosal immune defense. Immunity 29, 958-970.

Sawa, S., Cherrier, M., Lochner, M. Satoh-Takayama, N., Fehling, H. J. Langa, F., Di Santo, J. P., and Eberl, G (2010). Lineage relationship analysis of ROR $\gamma^{+}$innate lymphoid cells. Science 330, 665-669.

Sawa, S., Lochner, M., Satoh-Takayama, N., Dulauroy, S., Bérard, M., Kleinschek, M., Cua, D., Di Santo, J. P., and Eberl, G. (2011). ROR $\gamma \mathrm{t}^{+}$innate lymphoid cells regulate intestinal homeostasis by integrating negative signals from the symbiotic microbiota. Nat. Immunol. 12, 320-326.

Scandella, E., Bolinger, B., Lattmann, E., Miller, S., Favre, S., Littman, D. R., Finke, D., Luther, S. A., Junt, T., and Ludewig, B. (2008). Restoration of lymphoid organ integrity through the interaction of lymphoid tissueinducer cells with stroma of the $\mathrm{T}$ cell zone. Nat. Immunol. 9, 667-675.

Schmitz, J., Owyang, A., Oldham, E., Song, Y., Murphy, E., McClanahan T. K., Zurawski, G., Moshrefi, M., Qin, J., Li, X., Gorman, D. M., Bazan, J. F., and Kastelein, R. A. (2005). IL-33, an interleukin-1-like cytokine that signals via the IL-1 receptorrelated protein ST2 and induces T helper type 2-associated cytokines. Immunity 23, 479-490.

Schwarz, B. A., Sambandam, A., Maillard, I., Harman, B. C., Love, P. E., and Bhandoola, A. (2007). Selective thymus settling regulated by cytokine and chemokine receptors. J. Immunol. 178, 2008-2017.

Serwold, T., Ehrlich, L. I., and Weissman, I. L. (2009). Reductive isolation from bone marrow and blood implicates common lymphoid progenitors as the major source of thymopoiesis. Blood 113, 807-815.

Shimbara, A., Christodoulopoulos, P., Soussi-Gounni, A., Olivenstein, R.,
Nakamura, Y., Levitt, R. C., Nicolaides, N. C., Holroyd, K. J., Tsicopoulos, A., Lafitte, J. J., Wallaert, B., and Hamid, Q. A. (2000). IL9 and its receptor in allergic and nonallergic lung disease: increased expression in asthma. J. Allergy Clin. Immunol. 105, 108-115.

Sokol, C. L., Barton, G. M., Farr, A. G. and Medzhitov, R. (2008). A mechanism for the initiation of allergeninduced $\mathrm{T}$ helper type 2 responses. Nat. Immunol. 9, 10-18.

Sonnenberg, G. F., Monticelli, L. A., Elloso, M. M., Fouser, L. A., and Artis, D. (2011). CD4 ${ }^{+}$lymphoid tissue-inducer cells promote innate immunity in the gut. Immunity 34 , 122-134.

Soumelis, V., Reche, P. A., Kanzler, H., Yuan, W., Edward, G., Homey, B., Gilliet, M., Ho, S., Antonenko, S., Lauerma, A., Smith, K., Gorman, D., Zurawski, S., Abrams, J., Menon, S., McClanahan, T., de WaalMalefyt, R., Bazan, F., Kastelein, R. A., and Liu, Y. J. (2002). Human epithelial cells trigger dendritic cell mediated allergic inflammation by producing TSLP. Nat. Immunol. 3, 673-680.

Spits, H., and Di Santo, J. P. (2011). The expanding family of innate lymphoid cells: regulators and effectors of immunity and tissue remodeling. Nat. Immunol. 12, 21-27.

Srinivas, S., Watanabe, T., Lin, C. S., William, C. M., Tanabe, Y., Jessell, T. M., and Costantini, F. (2001). Cre reporter strains produced by targeted insertion of EYFP and ECFP into the ROSA26 locus. BMC Dev. Biol. 1, 4. doi:10.1186/1471-213X-1-4

Sun, Z., Unutmaz, D., Zou, Y. R., Sunshine, M. J., Pierani, A., BrennerMorton, S., Mebius, R. E., and Littman, D. R. (2000). Requirement for ROR $\gamma$ in thymocyte survival and lymphoid organ development. Science 288, 2369-2373.

Takatori, H., Kanno, Y., Watford, W. T., Tato, C. M., Weiss, G., Ivanov, I. I., Littman, D. R., and O'Shea, J. J. (2009). Lymphoid tissue inducerlike cells are an innate source of IL-17 and IL-22. J. Exp. Med. 206, $35-41$.

Takayama, T., Kamada, N., Chinen, H., Okamoto, S., Kitazume, M. T., Chang, J., Matuzaki, Y., Suzuki, S. Sugita, A., Koganei, K., Hisamatsu, T., Kanai, T., and Hibi, T. (2010) Imbalance of NKp44+ NKp46- and NKp44-NKp46 ${ }^{+}$natural killer cells in the intestinal mucosa of patients with Crohn's disease. Gastroenterol ogy 139, 882-892. 
Tan, C., Aziz, M. K., Lovaas, J. D., Vistica, B. P., Shi, G., Wawrousek, E. F., and Gery, I. (2010). Antigen-specific Th9 cells exhibit uniqueness in their kinetics of cytokine production and short retention at the inflammatory site. J. Immunol. 185, 6795-6801.

Temann, U. A., Geba, G. P., Rankin, J. A., and Flavell, R. A. (1998). Expression of interleukin 9 in the lungs of transgenic mice causes airway inflammation, mast cell hyperplasia, and bronchial hyperresponsiveness. J. Exp. Med. 188, 1307-1320.

Temann, U. A., Laouar, Y., Eynon, E. E., Homer, R., and Flavell, R. A. (2007). IL9 leads to airway inflammation by inducing IL13 expression in airway epithelial cells. Int. Immunol. 19, $1-10$.

Temann, U. A., Ray, P., and Flavell, R. A. (2002). Pulmonary overexpression of IL- 9 induces Th2 cytokine expression, leading to immune pathology. J. Clin. Invest. 109, 29-39.

Terashima, A., Watarai, H., Inoue, S., Sekine, E., Nakagawa, R., Hase, K., Iwamura, C., Nakajima, H., Nakayama, T., and Taniguchi, M. (2008). A novel subset of mouse NKT cells bearing the IL-17 receptor $\mathrm{B}$ responds to IL-25 and contributes to airway hyperreactivity. $J$. Exp. Med. 205, 2727-2733.

Townsend, J. M., Fallon, G. P., Matthews, J. D., Smith, P., Jolin, E. H., and McKenzie, N. A. (2000). IL-9deficient mice establish fundamental roles for IL-9 in pulmonary mastocytosis and goblet cell hyperplasia but not $\mathrm{T}$ cell development. Immunity 13, 573-583.

Trinchieri, G. (1989). Biology of natural killer cells. Adv. Immunol. 47, 187-376.

Tsuji, M., Suzuki, K., Kitamura, H., Maruya, M., Kinoshita, K., Ivanov, I. I., Itoh, K., Littman, D. R., and Fagarasan, S. (2008). Requirement for lymphoid tissue-inducer cells in isolated follicle formation and $\mathrm{T}$ cell-independent immunoglobulin A generation in the gut. Immunity 29, 261-271.

Turnquist, H. R., Zhao, Z., Rosborough, B. R., Liu, Q., Castellaneta, A., Isse, K., Wang, Z., Lang, M., Stolz, D. B., Zheng, X. X., Demetris, A. J., Liew, F. Y., Wood, K. J., and Thomson, A. W. (2011). IL-33 expands suppressive $\mathrm{CD} 11 \mathrm{~b}^{+} \mathrm{Gr}-1$ int and regulatory $\mathrm{T}$ cells, including $\mathrm{ST}_{2} \mathrm{~L}^{+}$Foxp $3^{+}$ cells, and mediates regulatory $\mathrm{T}$ celldependent promotion of cardiac allograft survival. J. Immunol. 187, 4598-4610.

Urban, J. F. Jr., Noben-Trauth, N., Donaldson, D. D., Madden, K. B., Morris,
S. C., Collins, M., and Finkelman, F. D. (1998). L-13, IL-4R $\alpha$, and Stat6 are required for the expulsion of the gastrointestinal nematode parasite Nippostrongylus brasiliensis. Immunity 8, 255-264.

Van Bruaene, N., Pérez-Novo, C. A., Basinski, T. M., Van Zele, T., Holtappels, G., De Ruyck, N., SchmidtWeber, C., Akdis, C., Van Cauwenberge, P., Bachert, C., and Gevaert, P. (2008). T-cell regulation in chronic paranasal sinus disease. J. Allergy Clin. Immunol. 121, 1435-1441.

van de Pavert, S. A., Olivier, B. J., Goverse, G., Vondenhoff, M. F., Greuter, M., Beke, P., Kusser, K., Höpken, U. E., Lipp, M., Niederreither, K., Blomhoff, R., Sitnik, K., Agace, W. W., Randall, T. D., de Jonge, W. J., and Mebius, R. E. (2009). Chemokine CXCL13 is essential for lymph node initiation and is induced by retinoic acid and neuronal stimulation. Nat. Immunol. 10, 1193-9119.

Van Maele, L., Carnoy, C., Cayet, D., Songhet, P., Dumoutier, L., Ferrero, I., Janot, L., Erard, F., Bertout, J., Leger, H., Sebbane, F., Benecke, A., Renauld, J. C., Hardt, W. D., Ryffel, B., and Sirard, J. C. (2010). TLR5 signaling stimulates the innate production of IL-17 and IL-22 by CD3negCD $127^{+}$immune cells in spleen and mucosa. J. Immunol. 185 1177-1185.

Veiga-Fernandes, H., Coles, M. C., Foster, K. E., Patel, A., Williams, A., Natarajan, D., Barlow, A., Pachnis, V., and Kioussis, D. (2007). Tyrosine kinase receptor RET is a key regulator of Peyer's patch organogenesis. Nature 446, 547-551.

Voehringer, D., Reese, T. A., Huang, X., Shinkai, K., and Locksley, R. M. (2006). Type 2 immunity is controlled by IL-4/IL-13 expression in hematopoietic non-eosinophil cells of the innate immune system. J. Exp. Med. 203, 1435-1446.

Vonarbourg, C., Mortha, A., Bui, V. L., Hernandez, P. P., Kiss, E. A., Hoyler, T., Flach, M., Bengsch, B., Thimme, R., Hölscher, C., Hönig, M., Pannicke, U., Schwarz, K., Ware, C. F., Finke, D., and Diefenbach, A. (2010). Regulated expression of nuclear receptor ROR $\gamma \mathrm{t}$ confers distinct functional fates to NK cell receptorexpressing ROR $\gamma \mathrm{t}^{+}$innate lymphocytes. Immunity 33, 736-751.

Vosshenrich, C. A., Ranson, T., Samson, S. I., Corcuff, E., Colucci, F., Rosmaraki, E. E., and Di Santo, J. P. (2005). Roles for common cytokine receptor $\gamma$-chaindependent cytokines in the generation, differentiation, and maturation of NK cell precursors and peripheral NK cells in vivo. J. Immunol. 174 1213-1221.

Vosshenrich, C. A., García-Ojeda, M. E., Samson-Villéger, S. I., Pasqualetto V., Enault, L., Richard-Le Goff, O. Corcuff, E., Guy-Grand, D., Rocha, B., Cumano, A., Rogge, L., Ezine, S. and Di Santo J. P. (2006). A thymic pathway of mouse natural killer cell development characterized by expression of GATA-3 and CD127. Nat. Immunol. 7, 1217-1224.

Walter, D. M., McIntire, J. J., Berry, G., McKenzie, A. N., Donaldson, D D., DeKruyff, R. H., and Umetsu, D. T. (2001). Critical role for IL13 in the development of allergeninduced airway hyperreactivity. $J$ Immunol. 167, 4668-4675.

Walzer, T., Bléry, M., Chaix, J., Fuseri, N., Chasson, L., Robbins, S. H., Jaeger S., André, P., Gauthier, L., Daniel, L., Chemin, K., Morel, Y., Dalod, M. Imbert, J., Pierres, M., Moretta, A., Romagné, F., and Vivier, E. (2007) Identification, activation, and selective in vivo ablation of mouse NK cells via NKp46. Proc. Natl. Acad. Sci. U.S.A. 104, 3384-3389.

Wang, Y. H., Voo, K. S., Liu, B., Chen, C. Y., Uygungil, B., Spoede, W., Bernstein, J. A., Huston, D. P., and Liu, Y. J. (2010). A novel subset of CD4 ${ }^{+}$ TH2 memory/effector cells that produce inflammatory IL-17 cytokine and promote the exacerbation of chronic allergic asthma. J. Exp. Med. 207, 2479-2491.

Welner, R. S., Esplin, B. L., Garrett, K. P., Pelayo, R., Luche, H., Fehling, H J., and Kincade, P. W. (2009). Asynchronous RAG-1 expression during B lymphopoiesis. J. Immunol. 183, 7768-7777.

White, B., Leon, F., White, W., and Robbie, G. (2009). Two first-in-human, open-label, phase I dose-escalation safety trials of MEDI-528, a monoclonal antibody against interleukin9, in healthy adult volunteers. Clin. Ther. 31, 728-740.

Wilhelm, C., Hirota, K., Stieglitz, B. Van Snick, J., Tolaini, M., Lahl, K., Sparwasser, T., Helmby, H., and Stockinger, B. (2011). An IL-9 fate reporter demonstrates the induction of an innate IL-9 response in lung inflammation. Nat. Immunol. 12, 1071-1077.

Wolk, K., Kunz, S., Witte, E., Friedrich, M., Asadullah, K., and Sabat, R. (2004). IL-22 increases the innate immunity of tissues. Immunity 21, 241-254.

Wolk, K., Witte, E., Wallace, E., Döcke, W. D., Kunz, S., Asadullah, K., Volk, H. D., Sterry, W., and Sabat, R.
(2006). IL-22 regulates the expression of genes responsible for antimicrobial defense, cellular differentiation, and mobility in keratinocytes: a potential role in psoriasis. Eur. J. Immunol. 36, 1309-1323.

Wolk, K., Witte, E., Witte, K., Warszawska, K., and Sabat, R. (2010). Biology of interleukin-22. Semin. Immunopathol. 32, 17-31.

Wong, S. H., Walker, J. A., Jolin, H. E., Drynan, L. F., Hams, E., Camelo, A., Barlow, J. L., Neill, D. R., Panova, V., Koch, U., Radtke, F., Hardman, C. S., Hwang, Y. Y., Fallon, P. G., and McKenzie, A. N. (2012). Transcription factor ROR $\alpha$ is critical for nuocyte development. Nat. Immunol. 13, 229-236.

Wynn, T. A. (2003). IL-13 effector functions. Annu. Rev. Immunol. 2, 425-456.

Yang, Q., Li, G., Zhu, Y., Liu, L., Chen, E., Turnquist, H., Zhang, X., Finn, O. J., Chen, X., and Lu, B. (2011a). IL-33 synergizes with TCR and IL12 signaling to promote the effector function of $\mathrm{CD}^{+} \mathrm{T}$ cells. Eur. J. Immunol. 41, 3351-3360.

Yang, Q., Saenz, S. A., Zlotoff, D. A., Artis, D., and Bhandoola, A. (2011b). Cutting edge: natural helper cells derive from lymphoid progenitors. J. Immunol. 187, 5505-5509.

Ying, S., O’Connor, B., Ratoff, J., Meng, Q., Mallett, K., Cousins, D., Robinson, D., Zhang, G., Zhao, J., Lee, T. H., and Corrigan, C. (2005). Thymic stromal lymphopoietin expression is increased in asthmatic airways and correlates with expression of Th2-attracting chemokines and disease severity. J. Immunol. 174, 8183-8190.

Yokota, Y., Mansouri, A., Mori, S., Sugawara, S., Adachi, S., Nishikawa, S., and Gruss, P. (1999). Development of peripheral lymphoid organs and natural killer cells depends on the helix-loop-helix inhibitor Id2. Nature 397, 702-706.

Yoshida, H., Kawamoto, H., Santee, S. M., Hashi, H., Honda, K., Nishikawa, S., Ware, C. F., Katsura, Y., and Nishikawa, S. I. (2001). Expression of $\alpha 4 \beta 7$ integrin defines a distinct pathway of lymphoid progenitors committed to $\mathrm{T}$ cells, fetal intestinal lymphotoxin producer, NK, and dendritic cells. J. Immunol. 167, 2511-2521.

Zaph, C., Troy, A. E., Taylor, B. C. Berman-Booty, L. D., Guild, K. J., Du, Y., Yost, E. A., Gruber, A. D., May, M. J., Greten, F. R., Eckmann, L., Karin, M., and Artis, D. (2007). Epithelial-cell-intrinsic $\quad$ IKK- $\beta$ expression regulates intestinal 
immune homeostasis. Nature 446, 552-556.

Zenewicz, L. A., Yancopoulos, G. D., Valenzuela, D. M., Murphy, A. J., Stevens, S., and Flavell, R. A. (2008). Innate and adaptive interleukin22 protects mice from inflammatory bowel disease. Immunity 29, 947-957.

Zheng, Y., Valdez, P. A., Danilenko, D. M., Hu, Y., Sa, S. M., Gong, Q.,
Abbas, A. R., Modrusan, Z., Ghilardi, N., de Sauvage, F. J., and Ouyang, W. (2008). Interleukin-22 mediates early host defense against attaching and effacing bacterial pathogens. Nat. Med. 14, 282-289.

Conflict of Interest Statement: Shigeo Koyasu is a consultant for Medical and Biological Laboratories, Co. Ltd.
The authors otherwise have no financial conflicts of interest.

Received: 26 December 2011; paper pending published: 16 January 2012; accepted: 15 April 2012; published online: 07 May 2012.

Citation: Koyasu S and Moro K (2012) Role of innate lymphocytes in infection and inflammation. Front. Immun. 3:101. doi: 10.3389/fimmu.2012.00101
This article was submitted to Frontiers in Inflammation, a specialty of Frontiers in Immunology.

Copyright (C) 2012 Koyasu and Moro. This is an open-access article distributed under the terms of the Creative Commons Attribution Non Commercial License, which permits non-commercial use, distribution, and reproduction in other forums, provided the original authors and source are credited. 